University of Chicago Law School

Chicago Unbound

Journal Articles

Faculty Scholarship

1977

\title{
Search for Sentencing Equity: Sentence Review in Massachusetts and Connecticut
}

Hans Zeisel

Shari Seldman Diamond

Follow this and additional works at: https://chicagounbound.uchicago.edu/journal_articles

Part of the Law Commons

\section{Recommended Citation}

Hans Zeisel \& Shari Seldman Diamond, "Search for Sentencing Equity: Sentence Review in Massachusetts and Connecticut," 1977 American Bar Foundation Research Journal 881 (1977).

This Article is brought to you for free and open access by the Faculty Scholarship at Chicago Unbound. It has been accepted for inclusion in Journal Articles by an authorized administrator of Chicago Unbound. For more information, please contact unbound@law.uchicago.edu. 


\section{Search for Sentencing Equity: Sentence Review in Massachusetts and Connecticut}

Hans Zeisel and Shari Seidman Diamond

\section{Contents}

Introduction $\ldots \ldots \ldots \ldots \ldots \ldots \ldots \ldots \ldots \ldots \ldots . \ldots \ldots$

I. Summary $\ldots \ldots \ldots \ldots \ldots \ldots \ldots \ldots \ldots \ldots \ldots \ldots \ldots \ldots$

History $885 \square$ Frequency of Appeal $886 \square$ Frequency of Modification $887 \square$ Sentence Increases $887 \square$ Sentencing Levels $887 \square$ Reasons for Modifications $888 \square$ Connecticut Requires Reasons $888 \square$ Composition of the Board $888 \square$ The Board's Direct Effect $888 \square$ The Board's Indirect Effect $889 \square$ The Search for Equity 889

II. History . . . . . . . . . . . . . . . . 890

III. The Review Procedure . . . . . . . . . . . . . 892 Massachusetts $892 \square$ Connecticut 894

IV. The Study Design . . . . . . . . . . . . . . . . 895

V. Main Patterns of Appeal and Disposition . . . . . . . . 897

VI. Severity of the Original Sentence . . . . . . . . . . . 899

VII. Sentence Imposed After Trial and After Guilty Plea . . . . . . 902

VIII. Identity of the Sentencing Judges $\ldots \ldots \ldots \ldots \ldots \ldots \ldots . \ldots 96$

IX. Size of Sentence Reductions . . . . . . . . . . . 908

X. Reasons for Reductions: Connecticut . . . . . . . . . . . 909

XI. Reasons for Reductions: Massachusetts . . . . . . . . . 918

XII. Sentence Increases . . . . . . . . . . . . . . . 923

XIII. The Value of Stated "Reasons" ............... 928

XIV. The Search for Equity . ................ 934 
HeinOnline -- 1977 Am. B. Found. Res. J. 8821977 


\title{
Search for Sentencing Equity: Sentence Review in Massachusetts and Connecticut
}

\author{
Hans Zeisel and Shari Seidman Diamond
}

\begin{abstract}
Grievances and restlessness among convicted prisoners led to legislation-in 1943 in Massacbusetts, in 1957 in Connecticut-establishing sentence review boards composed of tbree judges of the trial courts of first instance. The autbors explore in these two jurisdictions bow often and under what circumstances sentences are appealed and modified and what effect, if any, these modifications bave on the sentencing practice in the trial courts. They also appraise the value of the Connecticut requirement that the review board state the reasons for its decisions. The autbors explore the function of the review boards in the broader context of the need for reducing sentence disparity.
\end{abstract}

\section{INTRODUCTION}

Nowhere is the problem of sentence disparity more acute than in the American judicial system. Wide sentencing frames, almost complete discretion of the sentencing judge within those frames, and the lack of effective guidelines allow sentences to differ widely for no other reason

Hans Zeisel is Professor Emeritus of Law and Sociology, Research Associate, Center for Studies in Criminal Justice, the University of Chicago; Senior Consultant, American Bar Foundation.

Shari Seidman Diamond is Assistant Professor of Criminal Justice and Psychology, University of Illinois at Chicago Circle.

This is the second report in fulfillment of a grant for studying institutions designed to reduce sentence disparity. The first study dealt with the sentencing councils in the federal courts (see note 4 infra). The grant was made by the Law Enforcement Assistance Administration to the Center for Studies in Criminal Justice at the University of Chicago Law School. Additional support for this study was provided by the Nancy G. and Raymond G. Feldman Fund for Research at the University of Chicago Law School. The project was cheerfully and patiently administered by our colleague Franklin E. Zimring. In Massachusetts our thanks for cooperation and information go to John Fiske, the executive secretary of the superior court; $C$. Eliot Sands, commissioner of probation; John O'Connor, chief probation officer for Suffolk County; John Burke, assistant executive secretary of the superior court; James P. McGuire, chief probation officer for Middlesex County; Daniel Jaffe of the Criminal History Systems Board; and Daniel Cooper, who coded the cases. In Connecticut we were greatly aided by Paul Paulten, executive secretary to the Appellate Review Division, and by Pamela Samuelson, who coded and contributed to the analysis of the results with help from Stephen Frazzini. We also owe thanks to the Computation Center of the University of Illinois, Chicago, for dependable assistance in the data analysis. 
than that the one was set by Judge $A$ and the other by Judge $B .^{1}$ And since as a rule a sentence cannot be appealed unless the conviction itself is attacked, these disparate sentences stand-a matter of concern to the offender, the judge, and the criminal justice system as a whole. The fact of sentence disparity is well established, but until recently the size of such disparities had not been known. ${ }^{2}$

Two studies have recently supplied convincing data on the amount of sentence disparity. In 1974 the Federal Judicial Center published an experiment in which the judges in the Second Federal Circuit were asked to read summaries and presentence reports in 20 selected cases and indicate the sentence they would give in each. ${ }^{3}$ Although the study was designed to find out whether some judges were generally more severe than others, the data allowed us to determine the extent to which sentences varied among judges. The potential objection to such a study was that the results of the simulated situation would not necessarily reflect the real situation. That objection was to a great extent avoided in another effort to study sentence disparity in the federal courts, conducted in partial fulfillment of the present grant; it evaluated the sentencing councils in two of the four federal district courts in which the councils now operate. ${ }^{4}$ In these courts the trial judge, before pronouncing sentence, confers with some of his colleagues to find out what sentence they would impose in the particular case. Except for personal acquaintance with the defendant, these colleagues are provided

1. Cf. Marvin E. Frankel, Criminal Sentences: Law Without Order (New York: Hill and Wang, 1973).

2. Some studies compared overall sentencing patterns across judges on the assumption that random assignment of cases produced comparable sets of offenders and offenses for each judge to sentence (e.g., Frederick Gaudet, Individual Differences in the Sentencing of Judges, 32 Arch. Psychology 1 (1938); George Everson, The Human Element in Justice, $10 \mathrm{~J}$. Crim. L. \& Criminology 90 (1919)). In practice, considerations of court management (e.g., bypassing a judge already burdened with one or more long trials) or simple carelessness may interfere with a random assignment rule. In addition if judges differ in their rates of conviction or their rates of guilty plea, their mix of cases will differ at sentencing even if random assignment of cases has been strictly followed.

Other studies attempted to identify comparable cases assigned to different judges by holding constant characteristics likely to affect the sentence (e.g., offense, offender record). These studies (e.g., Edward Green, Judicial Attitudes in Sentencing: A Study of the Factors Underlying the Sentencing Practice of the Criminal Court of Philadelphia (Cambridge Studies in Criminology vol. 15) (London: Macmillan, 1961); Roger Hood, Sentencing in Magistrates' Courts: A Study in Variations of Policy 123 (Library of Criminology, Delinquency, and Deviant Social Behaviour No. 7) (London: Stevens \& Sons, 1962)) could always be criticized on the grounds that no two cases are ever alike and hence any differences might be due to cases rather than differences between judges.

3. Anthony Partridge \& William B. Eldridge, The Second Circuit Sentencing Study: A Report to the Judges of the Second Circuit (Washington, D.C.: Government Printing Office, 1974).

4. Shari Seidman Diamond \&.Hans Zeisel, Sentencing Councils: A Study of Sentence Disparity and Its Reduction, 43 U. Chi. L. Rev. 109 (1975). 
with all the documents and facts potentially related to the sentencing decision which are available to the trial judge. All participating judges, therefore, come as close to making a real sentencing decision as judges ever will, short of replacing the single trial judge by a collegium of judges.

The study found that the sentences imposed by two judges chosen at random from the court differed on the average by 37 percent of the mean of the two in the United States District Court for the Northern District of Illinois, and by 46 percent of the mean of the two in the United States District Court for the Eastern District of New York. ${ }^{5}$ Since the latter was one of the courts in which the Federal Judicial Center study was carried out, we could compare the disparity figures from our sentencing council data with the simulated experiment. The juxtaposition gave startling support to our results: Federal Judicial Center experiment-48 percent; sentencing council data-46 percent. ${ }^{6}$ The identity in outcome buttresses the finding and also tends to validate the method of measuring disparity with the aid of simulated sentencing. The sentencing councils in the federal courts, incidentally, proved to be of little help. They reduced the original disparity by only a modest amount: in the Chicago court, from 37 percent to 33 percent; in the New York court, from 46 percent to 41 percent. $^{7}$

The present study examines another of the few existing remedies for sentence disparity: the appeal of sentences to a Sentencing Review Board composed of three trial judges from the courts of first instance. Massachusetts invented the institution, and Connecticut followed suit with one important additional innovation: the Connecticut review division is required to give reasons for its decisions. Since this is one of the few places in the American legal system in which sentence decisions must be supported by a written opinion, ${ }^{8}$ it was an opportunity to learn something about the potential usefulness of that requirement.

\section{SUMMARY}

\section{History}

Grievances and restlessness among convicted prisoners led to legislation, in 1943 in Massachusetts, in 1957 in Connecticut, which estab-

5. With the mean of the two sentences equaling 100 percent. Id. at 123 , table 6 .

6. Id. at 146 , table 27 .

7. Id. at 137 .

8. Maine requires trial judges to give reasons at original sentencing. Me. Rev. Stat. Ann. tit. 15, secs. 2141-2144 (Supp. 1975). Maryland requires statements of reasons in all appealed cases. Md. Ann. Code art. 27, secs. 645JA-645JG (1976), rule 762 (1977). 
lished a sentence review division that consists of three judges of the trial courts of first instance, and all offenders sent to prison may ask for review. The board may reduce the sentence, but may also increase it. Connecticut has not increased a sentence since 1963.

\section{Frequency of Appeal}

As table 1 shows, frequency of appeal varies with the severity of the original sentence; it also varies depending on whether the sentence was imposed after a guilty plea or after trial.

\section{TABLE 1}

Frequency of Appeal and Modification by Severity of Sentence and Type of Conviction (Percent)

\begin{tabular}{|c|c|c|c|c|c|c|c|c|}
\hline \multicolumn{9}{|c|}{ Massachusetts } \\
\hline & \multirow{2}{*}{\multicolumn{2}{|c|}{$\begin{array}{c}\text { Up to } 5 \text { Years } \\
\text { (Below the } \\
\text { Normal Level of } \\
\text { Consideration) }\end{array}$}} & \multicolumn{4}{|c|}{ Over 5 Years } & \multirow{2}{*}{\multicolumn{2}{|c|}{ Total }} \\
\hline & & & \multicolumn{2}{|c|}{$\begin{array}{c}\text { After } \\
\text { Guilty Plea }\end{array}$} & \multicolumn{2}{|c|}{ After Trial } & & \\
\hline No appeal . . . . & \multicolumn{2}{|r|}{97.7} & \multicolumn{2}{|r|}{81.0} & \multicolumn{2}{|r|}{61.8} & \multicolumn{2}{|r|}{68.8} \\
\hline Appeal ....... & \multicolumn{2}{|r|}{2.3} & \multicolumn{2}{|r|}{19.0} & \multicolumn{2}{|r|}{38.2} & \multicolumn{2}{|r|}{31.2} \\
\hline Affirmed .... & \multicolumn{2}{|l|}{2.1} & 14.0 & & 32.7 & & \multicolumn{2}{|l|}{10.7} \\
\hline Reduced . . . . . . & \multicolumn{2}{|l|}{0.2} & 4.6 & & \multicolumn{2}{|l|}{5.1} & \multicolumn{2}{|l|}{2.3} \\
\hline Increased $\ldots \ldots$ & . & & \multicolumn{2}{|l|}{0.4} & \multicolumn{2}{|l|}{0.4} & \multicolumn{2}{|l|}{0.2} \\
\hline Total ...... & \multicolumn{2}{|r|}{100.0} & \multicolumn{2}{|r|}{100.0} & \multicolumn{2}{|r|}{100.0} & \multicolumn{2}{|r|}{100.0} \\
\hline$\%$ Share ..... & \multicolumn{2}{|r|}{$(56)$} & & $(26)$ & \multirow{2}{*}{\multicolumn{2}{|c|}{$(18)$}} & \multicolumn{2}{|r|}{$(100)$} \\
\hline \multicolumn{7}{|c|}{ Connecticut } & & \\
\hline & \multicolumn{2}{|c|}{ Up to 3 Years } & \multicolumn{4}{|c|}{ Over 3 Years } & & \\
\hline & \multicolumn{2}{|c|}{$\begin{array}{l}\text { (Below the } \\
\text { Normal Level of } \\
\text { Consideration) }\end{array}$} & \multicolumn{2}{|c|}{$\begin{array}{c}\text { After } \\
\text { Guilty Plea }\end{array}$} & Afte & r Trial & & otal \\
\hline No appeal . . . . . & & 89.0 & & 75.2 & & 48.0 & & 83.1 \\
\hline Appeal . . . . . & & 11.0 & & 24.8 & & 52.0 & & 16.9 \\
\hline Affirmed .... & 10.8 & & 22.3 & & 44.0 & & 15.7 & \\
\hline Reduced ...... & 0.2 & & 2.5 & & 8.0 & & 1.2 & \\
\hline Increased .... & -- & & -- & & -- & $\underline{-}$ & -- & \\
\hline Total ...... & & 100.0 & & 100.0 & & 100.0 & & 100.0 \\
\hline$\%$ share ...... & & (63) & & (34) & & (3) & & $(100)$ \\
\hline
\end{tabular}

Sentences up to 5 years in Massachusetts and up to 3 years in Connecticut are hardly ever modified and hence seldom appealed. In both states these two groups, in fact excluded from review, form over one-half of all sentences the law made eligible for review. 
Sentences above these limits are appealed with some frequency, roughly twice as often after trial as after a guilty plea; of the Massachusetts sentences, 19 percent after guilty plea and 38 percent after trial; of the Connecticut sentences, 25 percent after guilty plea and 52 percent after trial.

\section{Frequency of Modification}

The overall modification rates are small in both states, primarily because sentences up to 3 years in Connecticut and up to 5 years in Massachusetts are hardly ever modified. Of all eligible sentences, Massachusetts reduced 2.3 percent and increased 0.2 percent, while Connecticut reduced 1.2 percent and increased none.

The modification rates are larger if computed for the sentences above the 3-year and 5-year limits. In Massachusetts roughly 5 percent of these sentences are reduced; the rate is not greater after trial than after guilty plea. In Connecticut, if one may trust the small sample of trials, the modification rate after trial is 8 percent, as against 3 percent after guilty plea.

\section{Sentence Increases}

Even the occasional upward modification of sentences by the Massachusetts Review Board, we assume, reduces disparity. What the appellant perceives as too high a sentence may be seen by the board as too low a sentence when compared to similar cases. These sentence increases are nevertheless problematic. The review board sees only sentences which the offender considers to be on the high side. Offenders who are satisfied with their sentences because they consider them adequate or even lenient do not appeal. The board, therefore, does not see the bulk of cases that may deserve upward revision. The disparities the board tries to correct by upward revisions all fall into the high sentence range of over 5 years. It is difficult to lose the feeling that the board deems it necessary to increase a sentence once in a while to keep this right from degenerating into a paper threat.

\section{Sentencing Levels}

Massachusetts prison sentences are on the whole considerably higher than prison sentences in Connecticut. Whether this indicates a generally more severe sentencing practice depends on the to-us-unknown proportion of defendants not sent to prison. 
The higher proportion of convictions after trial in Massachusetts (30 percent) than in Connecticut $(5$ percent) may conceivably reflect different practices of plea bargaining.

\section{Reasons for Modifications}

A few sentencing principles have been established by the boards. One is that codefendants with similar criminal records and equal share of guilt should receive similar sentences unless they can be distinguished, e.g., by a codefendant's having turned state's evidence (Connecticut and Massachusetts); or that the sentence for a juvenile should not be greater than the sentence an adult could have received had he been convicted of that crime (Connecticut).

In both states the most frequent reason for reducing a sentence is the review board's Gestalt perception that a particular sentence is out of line with the sentences ordinarily imposed for that particular crimeoffender combination.

\section{Connecticut Requires Reasons}

Requiring the board to write opinions, as Connecticut does, is potentially useful; opinions could become precedents, leading to guidelines. As presently written, the opinions seldom serve that purpose. More often than not they fail to articulate the reasons for rejecting or allowing the appeal, most probably because such articulation is difficult.

\section{Composition of the Board}

Some judges have more severe sentencing standards than others. Much depends, therefore, on the composition of the board. The Connecticut provisions recommend themselves; there, the trial court judges take turns in serving 3-year terms on the board. On a staggered basis, this gives each judge the opportunity to be associated during his term with four different colleagues. Such association, which eventually would involve all trial judges, might by itself increase the judges' awareness of their colleagues' sentencing views.

\section{The Board's Direct Effect}

The original amount of sentence disparity in Massachusetts and Connecticut (or for that matter in any state court) has not been measured. Such measures have been developed only for some federal courts. There the sentences of two judges, randomly selected from the court, sentencing the same case independently, will on the average differ by 
around 40 percent. Disparity in the state courts could be smaller because the crimes there are more homogeneous; moreover, if the prosecutor's office has influence on the sentencing process, it might reduce disparity. But if disparity in the state courts is anywhere near that in the federal courts, the 1 or 2 percent reductions by the review boards can make but a dent.

\section{The Board's Indirect Effect}

The most interesting question is whether the review board through its decisions contributes to a more general reduction of sentence disparity by allowing trial judges to see and comply with the board's standards. The present study was not designed to explore whether such a learning process takes place; only observance of sentencing pattern of individual judges over time in relation to reversals of their sentences by the board would provide the pertinent data. The modest evidence from the present study suggests that this indirect effect of the board is at best minimal. There are too few reductions per judge and there is hardly any effort to establish general standards from which the judges could learn.

In Massachusetts only the judge's own reversals-few and far between-come to his attention. In Connecticut the judges also have access to published opinions, but these appear infrequently; moreover, few of these opinions convey guidelines. It is difficult to see how even a judge eager to comply with the board's views can read them. The Massachusetts board gives no reasons, and our analysis has shown how difficult it is to infer reasons from the record. Connecticut, although it states reasons, fares not much better; more often than not the stated reasons are none.

The rare direct contacts of the trial judge with the decisions of the review board and the lack of specificity of reasoning in these cases make it improbable that messages are received by the trial judge that will change his future sentencing pattern.

The Search for Equity

A judge's first concern in pronouncing sentence is with the sentence's "vertical" justice, that it be just in terms of the judge's own scale of standards and values. Since that scale will vary from judge to judge, the requirement of "lateral" justice-of avoiding sentence disparity-arises. The problem is to reconcile the two conflicting requirements. Ultimately, sentencing guidelines should provide the solution. Their development must start with discovering and making explicit the 
sentencing pattern now prevalent in any given court system. That pattern should be made visible and eventually be used in the formulation of guidelines. They should involve narrower sentencing frames for corresponding narrower crime-offender combinations. The pioneering work of Leslie Wilkins has stimulated our thinking and an interim solution has been proposed that would provide continuous visibility of the disparity problem and of the need for lateral sentencing justice.

\section{HISTORY}

Soon after the first state prison in Massachusetts opened in 1805, complaints about disparity in sentencing began to accumulate. ${ }^{9}$ Some fifty years later Governor Nathaniel Banks recommended as remedy "an appeal to the full bench of the court in which sentence was pronounced, and authority given to lessen its rigor." 10 But it took almost another century until 1942, when after some unrest in its prisons, Massachusetts initiated action that eventually led to an appellate review procedure. The Judicial Council of Massachusetts recommended that an "appellate session" of the Superior Court be established for review of sentences. ${ }^{11}$ The council's report drew on the American Law Institute's model criminal code of $1930^{12}$ but left open the exact form the review procedure should take.

In the following year, 1943, Massachusetts passed the statute ${ }^{13}$ that created the Appellate Division of the Superior Court, with the authority to review all sentences to state prison of $2 \frac{1}{2}$ years or more. That statute has undergone only minor alterations. A 1945 amendment $^{14}$ made women sentenced to the reformatory for over 5 years also eligible for sentence appeal. A second 1945 enactment made sentence appeal retroactively available for 2 years to inmates serving prison sentences imposed before the review division had been created. ${ }^{15}$ Apart from three other minor technical changes, ${ }^{16}$ the provisions of the law have not changed. ${ }^{17}$

9. Edwin Powers, The Basic Structure of the Administration of Criminal Justice in Massachusetts 120 (6th ed. Boston: Massachusetts Correctional Association, 1973).

10. The governor's address to the Executive Council, Jan. 11, 1859, in 1858-59 Mass. Acts at 584 . 1942.

11. Eighteenth Report, Judicial Council of Massachusetts, 28-30, Public Document No. 144,

12. ALI Code of Criminal Procedure sec. 459 (June 15, 1930, Draft).

13. 1943 Mass. Acts ch, 558, sec. 1.

14. 1945 Mass. Acts ch. 255 , secs. 1-3. See note 31 infra.

15. Id. ch. 437.

16. 1955 Mass. Acts ch. 770, sec. 91, 1957 Mass. Acts ch. 777, sec. 36, changed the term used to refer to the "warden" to principal officer and then to "superintendent," 1968 Mass. Acts ch. 666 , secs. 1-4, eliminated the former (never used) "leave to appeal" provisions and gave 
Connecticut followed the example of Massachusetts in 1956, also after a series of militant uprisings at the prison during the summer months of that year. The governor appointed a committee to investigate the reasons for prisoner unrest and to propose legislation that would remedy legitimate prisoner grievances. The committee discovered that prisoners compared their sentences with those of fellow inmates and often complained of alleged inequities in the penalties imposed on similar offenders for similar offenses. ${ }^{18}$ At that time, the recipients of the harsher penalties had no way to challenge them as arbitrary or unreasonable because the Connecticut Supreme Court of Errors, like other courts across the land, had consistently refused to review a sentence unless it was in excess of the statutory maximum. ${ }^{19}$ The committee investigated and found "a marked variation in the sentences of prisoners who have substantially similar backgrounds and have been convicted of the same offense." 20 The committee cautioned that the issue was not so much whether actual disparity existed but rather that the prisoners believed it to exist: "As long as a prisoner feels that he has been denied review of a sentence which he deems unfair or unduly harsh, he remains a source of trouble in the prison system and efforts toward rehabilitation are seriously impeded." 12 The committee, therefore, recommended to the legislature that it establish a Sentence Review Division to which prisoners could apply for review.

The structure of the review division recommended by the committee and eventually adopted by the legislature was modeled on the Massachusetts system: ${ }^{22}$ (1) the board would consist of three trial court judges; (2) a judge who had imposed the original sentence could not participate in its review; (3) only the defendant, not the prosecutor, had

the appellate division the power to impose a modification instead of removing it for modification to the superior court.

17. Mass. Ann. Laws ch. 278, sec. 28A (Michie/Law. Co-op. Cum. Supp. 1977).

18. Connecticut Prison Study Committee, First Interim Report 1 (unpublished; Nov. 19, 1956) (hereinafter referred to as First Report).

19. State v. Horton, 132 Conn. Supp. 276, 43 A.2d 744 (1945); State v. La Porta, 140 Conn. Supp. 610, 102 A.2d 885 (1954).

20. First Report, supra note 18, at 3. The committee did a pilot investigation of 200 files at Wethersfield Prison. Concentrating on sentences of those convicted of robbery with violence, the committee found:

Among prisoners with a record of more than 1 major offense, sentences range from a low of 8 to 12 years to a high of 15 to 22 years. Among prisoners with a record of only minor offenses, sentences range from a low of 1 to 3 years to highs of 10 to 12 and 8 to 15 years. Among prisoners with no record of prior convictions, sentences range from a low of 1 to 3 to a high of 8 to 12 years.

Id.

21. Id. at 1 .

22. Id. 
the right to apply for review; ${ }^{23}$ (4) the tribunal could require the sentencing judge to provide a written statement of reasons for his original sentence; and (5) the tribunal would have the power to increase as well as reduce a sentence. ${ }^{24}$ In addition, and in contrast to Massachusetts, the Connecticut review division would be required to write an opinion in each decided case, and these opinions were to be published in an official volume of Connecticut Judicial Decisions. ${ }^{25}$ There was one other difference. The three members of the Massachusetts division are appointed "from time to time"; 26 the present ones have been serving since 1973, when the members of the previous panel were forced to resign because a mandatory retirement age of 70 had been established for Massachusetts judges. ${ }^{27}$ The Connecticut panel members serve three-year terms on a rotating basis.

The Connecticut legislature, with almost no opposition, enacted the sentence review bill in May $1957 . .^{28}$ The right to apply for review was made retroactive so that prisoners who had participated in the 1956 incidents of unrest could take advantage of the newly created right to review. The major purpose of the statute, as its proponents depicted it, was to lessen the potential for resentment among prisoners who thought their sentences unfair. ${ }^{29}$

\section{THE REVIEW PROCEDURE}

\section{Massachusetts}

In Massachusetts every defendant sentenced to state prison to serve a term of $2 \frac{1}{2}$ years or more not mandated by law ${ }^{30}$ or committed to

23. The committee thought allowing the state to apply for review of sentences would violate the double jeopardy clause of the Constitution. Id., Appendix.

24. The appendix to the committee's First Report argued that to give the division power to increase sentences would not violate the double jeopardy clause.

25. First Report, supra note 18, at 10-11.

26. Mass. Ann. Laws ch. 278, sec. 28A (Michie/Law. Co-op Cum. Supp. 1977).

27. Mass. Const. sec. 244, art. 98 amendments (1972).

28. 1957 Conn. Pub. Acts, Jan. Sess., P.A. 436. The first statute did not provide the division with power to increase sentences. The act was amended in September 1957 to provide that the division could increase sentences. Conn. Pub. Acts, Sept. Spec. Sess., P.A. 14.

29. Minutes of proceedings before the Joint Committee on the Judiciary and Governmental Functions, Feb. 28, 1957, at 404. See also comments by Representative Koskoff at the same hearing, at 374, and comments in House Proceedings, May 17, 1957, at 2379.

30. All sentences to state prison must be at least $2 \frac{1 / 2}{2}$ years with two exceptions. The first occurs when a prisoner is already serving a state prison sentence at the time of the act in which case a 1-year minimum is permissible (Mass. Laws Ann. ch. 279, sec. 26 (Michie/Law. Co-op 1968)). The second is on a second or subsequent conviction of violation of general drug laws leading to harmful drugs when a 2-year minimum is allowed (Mass. Laws Ann, ch. 94C, sec. 32 (Law. Co-op 1975)). Only 2 of 443 prison sentences in 1971 had minimums below 2 years. 
the Women's Reformatory for 5 years or more has a right to apply for sentence review. ${ }^{31}$

At the outset, hearings were held in Boston and at the Massachusetts Correctional Institution in Norfolk, but currently they are conducted in the basement of the Wrentham district courthouse, which is close to Walpole State Prison. Sessions are generally held twice a year, when the clerk of the Appellate Division notifies the chief justice that there are enough appeals on file to warrant a meeting. The division has sat for an average of about 16 days per year since it began reviewing cases in $1944 .{ }^{32}$

The offender who receives a sentence eligible for review is notified by the clerk of the trial court at the time of sentencing and then has ten days to file an-appeal. The execution of the sentence is not stayed by the filing of an appeal. If an appeal is filed, the trial court judge is notified and given the opportunity to submit his reasons for imposing the sentence, or the judge may be requested by the Appellate Division to provide such a statement. Neither hardly ever happens.

The proceedings before the division are informal. Although the defendant is generally represented by his counsel, ${ }^{33}$ the district attorney is generally a representative of the county whose cases are being heard on that day and is not necessarily the prosecutor in the particular case. A member of the county probation office will also usually be present. No court reporter takes notes and there is no record of the hearings. The judges have generally reviewed a summary of the case record and the report of the probation department before the hearing begins.

The offender is then brought in, and the clerk reads the indictment, the verdict, and the imposed sentence. The chairman of the division reminds the appellant that the division has the power both to raise and to lower sentences; and, when it is ascertained that this is understood, defense counsel proceeds with the argument. ${ }^{34}$ No witnesses are called, but letters and affidavits may be submitted. The prosecutor

31. See Mass. Ann. Laws ch. 278, sec. 28A (Michie/Law. Co-op Cum. Supp. 1977). The discrimination against women is avoided by the practice of sentencing women to "prison" and specifying that their sentence is to be served at the reformatory.

32. 1966 and 1967 are omitted because of missing data. Computed from annual reports to the justice of the supreme judicial court by the executive secretary supplemented by Daniel Bort, Criminal Sentence Appeal in Massachusetts (Unpublished paper, Harvard Law School, 1974).

33. This is his right (Petition of Croteau, 353 Mass. 736, 234 N.E.2d 737 (1968)), although on rare occasions it may be waived.

34. In the hearings I viewed (S.D.) this warning resulted in several withdrawals. These cannot be distinguished in the division or county records from withdrawals for other reasons. 
responds, there is an opportunity for rebuttal, and members of the division frequently question the attorneys. The offender has an opportunity to address the division, then the hearing ends. After several cases are heard, the division; meets in executive session. If a sentence is modified, the appellant and counsel are recalled and the new sentence is announced to them. Otherwise, counsel is told that the appeal is being "taken under advisement," which in practice means that it has been dismissed.

\section{Connecticut}

In Connecticut, every defendant sentenced to serve a prison or reformatory term of 1 year or more has the right to apply for review of that sentence. ${ }^{35}$ Application must be made within 30 days after sentencing. As in Massachusetts, the right is the defendant's alone; the state's attorney may not appeal. As in Massachusetts, the division has the power to increase the sentence. ${ }^{36}$ An appeal of the sentence does not stay its execution, ${ }^{37}$ but review is relatively prompt, occurring usually within four to six months after sentencing. ${ }^{38}$

Defendants whose sentences are reviewed are entitled to be represented during oral argument by their attorneys and by the state's attorney. Defendants, if they wish, may also make personal statements to the division.

Review hearings have always been conducted at the prison or reformatory, with about 25 cases scheduled for each session. A few days before the hearing, each judge receives a folder containing synopses prepared by the executive secretary of the division ${ }^{39}$ of all cases to be reviewed at that session and the full file on some offenders. Although sentencing judges can be required to submit reasons for their sentence, in practice this is never done. ${ }^{40}$ There are occasions when a sentencing judge, notified that a defendant sentenced by him has filed an appeal,

35. See Conn. Gen. Stat. Ann. sec. 51-195 (West Cum. Supp. 1977).

36. See $i d$. sec. 51-196.

37. See id. sec. 51-195.

38. The defendant can delay the review hearing if he wishes. In the sample of sentence review applicants of 1972,114 had hearings four to six months after the application was filed; 27 waited seven months or more.

39. The duties of the executive secretary include: (1) making sure the file for each applicant is complete; (2) assigning cases for hearings; (3) assuring representation by counsel of the applicant; (4) notifying defendants, attorneys, judges, and corrections officers when hearings will be held; (5) notifying when applications are untimely; (6) attending sentence review hearings; and (7) distributing the opinions.

40. See Conn. Gen. Stat. Ann. sec. 51-195 (West Cum. Supp. 1977). This is in part because sentencing hearing transcripts are available to review division. 
will write to the division explaining the sentence; in at least one case such an explanation supported the appeal. The judges do not limit the amount of time any participant may speak during the hearing-hearings lasting anywhere from five minutes to an hour and a half. After all cases are heard for the day, the judges go into executive session, with each judge being assigned to write the opinion in one-third of the cases.

The opinions are rarely longer than two pages and follow a standard formula: a statement that this defendant was convicted after a guilty plea or a trial for a certain offense or offenses; recitation of the statutory penalty for the offense(s); what the imposed sentence was; whether the charge was reduced or other counts nolle prossed or dismissed or both; a brief description of the facts of the offense(s); a statement about the offender's prior criminal record; remarks about the offender's character, habits and social adjustment; a conclusion that the sentence is fair and should stand or is excessive under the circumstances. Not all opinions are this complete; some contain more detail than others.

Within three or four weeks the opinion usually has been written and is distributed to the defendant, his counsel, the state's attorney, the sentencing judge, and a few other persons. ${ }^{41}$ If the sentence is ordered modified or the defendant is ordered released, the process is expedited.

\section{THE STUDY DESIGN}

This study was designed to find out how often and under what circumstances sentence appeals are filed in Massachusetts and Connecticut, ${ }^{42}$ when and why they result in a modification of the sentence. To the extent that it was possible we also wanted to find out what effect the review procedures have on the sentencing practice of the trial courts. We have paid special attention to the unique feature of the Connecticut system that requires reasoned written opinions in each case as to why a sentence was or was not modified.

The Massachusetts sample of cases consisted of all offenders sentenced to state prison (and therefore eligible for sentence review) between November 1, 1972, and December 31, 1973, in two major

41. Other parties to whom opinions are regularly sent are: the chief justice of the Connecticut Supreme Court, the state's attorney in Hartford, the warden of the institution at which the prisoner is confined, the supreme court reporter, the state library, and, if it is to be published, to the Hartford Times and Hartford Courant.

42. The only prior study of appellate review of sentences in Connecticut was published 18 years ago. See Note, Appellate Review of Primary Sentencing Decisions: A Connecticut Case Study, 69 Yale L.J. 1453, 1464 (1960). 
Massachusetts counties-Suffolk and Middlesex-which generate approximately one-half of all Massachusetts prison sentences. After adding an additional sample of appealed cases, the analysis is based on 775 units, the appropriately weighted sample of 436 cases. $^{43}$

In Connecticut we recorded and analyzed all appeals filed with the Sentence Review Division in 1962, 1967, and 1972, including both superior and circuit court cases. In addition, to learn something about the cases eligible for appeal in which no appeal was filed, we took three samples of 75 cases each from the files of three principal superior courts-Hartford, New Haven, and Fairfield-which together account for more than half of the state's superior court business. We thus have a complete representation of all appeals filed in the years 1962, 1967, and 1972 (496 cases). We also have, based on a sample, all eligible defendants for the 1972 sentences in the three above-mentioned courts. Thus the Connecticut analysis is based on 918 units, the appropriately

43. The following table presents a synopsis of the Massachusetts cases in this study:

TABLEA

Middlesex County

(a) Nov. 1, 1972-Dec. 31,

1973 ............... 107

(nonapplicants) ........ (75) -6 suspended

(applicants) ......... (32)

(b) additional sample with suspended sentences (all nonapplicants), Oct.

1972 ..............

(c) additional applicant sample (Oct. 1973, Apr. \& Sept.

1974) ...............
Suffolk County

(a) Nov. 1, 1972-Dec. 31, $1973 \ldots \ldots \ldots \ldots \ldots \ldots 299$

(nonapplicants) ........ (210)

(applicants) .......... (89)

(a) The Massachusetts sample was obtained from the probation office records of Suffolk and Middlesex counties for the 14 months between Nov. 1, 1972, and Dec. 31, 1973 (see table A).

(b) Middlesex County only: Since the probation files in Middlesex recorded suspended sentences for only 3 of the 14 months (recording stopped after Jan. 1973), additional suspended sentence cases were obtained from Oct. 1972. The 13 suspended sentences were then weighted by $14 / 4$ to account for the omissions in the sample between Feb. 1973 and Dec. 31, 1973. $(14 / 4 \times 13)+101=147$ units.

(c) Since the majority of those eligible for appeal do not take their cases to the review board, an additional sample of applicants was drawn so that this group could be examined in greater detail. The additional cases were those scheduled to be heard by the division during Oct. 1973, Apr. 1974, and Sept. 1974. This added 79 cases for Suffolk County and 14 cases for Middlesex County. Since these cases were all applicants, the 210 nonapplicant cases of Suffolk County were weighted by $(79+89) / 89$, and the 115 nonapplicant cases in Middlesex County by $(14+32) / 32$. The final sample, on which all calculations are based, therefore consists of 564 Suffolk County units and 211 Middlesex County units, for a total of $\mathbf{7 7 5}$ units. 
weighted sample of 443 cases. ${ }^{44}$ In Connecticut, eligibility for appeal requires that the sentence be a potential maximum of at least 1 year; in Massachusetts, $2 \frac{1}{2}$ years. Since this study generally compares the two states, we have eliminated in many tables the 67 offenders from the 1972 Connecticut Superior Court sample (7 percent of the total) who had sentences below the $2 \frac{1 / 2}{2}$ years so as to make the offender populations for the two states comparable. ${ }^{45}$ This leaves the primary Connecticut sample at $851(918-67)$ units.

\section{MAIN PATTERNS OF APPEAL AND DISPOSITION}

The comprehensive picture as it emerges from our sample for the Connecticut courts is presented in table 2 .

\section{TABLE 2}

Sentence Review Pattern in Connecticut Superior Courts, 1972

\begin{tabular}{|c|c|c|c|}
\hline & \multicolumn{2}{|c|}{$\begin{array}{l}\text { Percent of } \\
\text { Eligible Cases } \\
(N=918)\end{array}$} & $\begin{array}{l}\text { Percent of } \\
\text { Appeals Heard } \\
(N=155)\end{array}$ \\
\hline No appeal & & 76.3 & \\
\hline Appeal withdrawn ... & & 6.8 & \\
\hline Appeal . . . . . . . . & & 16.9 & \\
\hline Affirmed & 15.7 & & 93 \\
\hline Increased . . . . . . & - & & - \\
\hline Reduced ....... & 1.2 & & 7 \\
\hline Total ....... & & 100.0 & 100 \\
\hline
\end{tabular}

Seventy-six percent of all offenders eligible for appeal never filed one; of the remaining 24 percent who did ask for a review, 7 percent later withdrew their requests. Thus, the division reviewed 17 percent of

44. (a) The 75 nonapplicants from each of the three superior court counties were weighted by the actual number of 1972 nonapplicants from that county. Thus, there were 137 nonapplicants from Fairfield County in 1972 and the 75 sampled nonapplicants were weighted by 137/75; similarly the 75 sampled nonapplicants from Hartford County were weighted by $220 / 75$ and the 75 sampled nonapplicants from New Haven County by $114 / 75$. These weighting procedures resulted in $137+220+114=471$ nonapplicant units.

(b) There were 218 applicants in 1972 from all superior courts. There were 471 nonapplicants from the three sampled counties and 229 from other superior courts. The 471 units from the sampled counties were therefore weighted by $700 / 471$ to estimate the 1972 nonapplicant cases in all superior courts.

(c) When the 700 nonapplicant units are added to the 218 applicants, the sample contains 918 units representing all superior court cases eligible for sentence review in 1972 .

45. In none of the eliminated cases was the sentence reduced: 58 were not appealed; in 3 cases an appeal was made and withdrawn; the six maintained appeals were all unsuccessful. 
the eligible sentences, or roughly one out of every six. Of the reviewed sentences, 7 percent were reduced, amounting to 1.2 percent of all imposed sentences eligible for review. There has been no sentence increase in Connecticut since 1963.

The disposition pattern did not change significantly over time, as the following table for Connecticut shows.

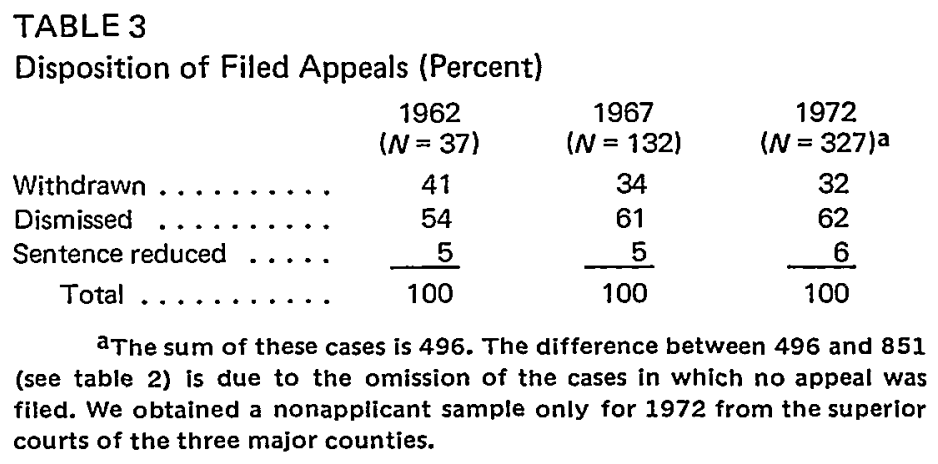

In Massachusetts the comparable statistics as provided by our sample have to be adjusted. Among the 506 cases in our sample there was not one sentence increase, but we know from the statistics compiled each year by the Executive Secretary of the Massachusetts Superior Court $^{46}$ that the division does occasionally increase sentences. Over a five-year period the division reviewed 935 sentences, increased 14 (1.5 percent), and reduced 144 ( 15.4 percent). The ratio of reductions to increases, therefore, is about ten to one. On this basis one would have expected one or two increases in our sample of 506 cases. That we found none is well within the vagaries of the sampling error. In the following table (table 4) we have added sentence increases as expected (and not as we found them) so as to give the best estimate of the real situation. The share of dismissals is correspondingly reduced. Of all eligible offenders 27 percent filed an appeal, but roughly one-half of these appeals were withdrawn, so that 13 percent of all eligible offenders asked for and obtained a review hearing. In 21 percent of these hearings the sentence was modified; 19 percent were reductions, and 2 percent were increases. Thus, on the average, of all eligible sentences, 23 out of every 1,000 are reduced, and 2 out of every 1,000 are increased.

46. Fourteenth through Eighteenth Annual Reports to the Justices of the Supreme Judicial Court by the Executive Secretary (Public Document No. 166) June 30, 1970, 1971, 1972, 1973 , and 1974. 
TABLE 4

Sentencing Review Pattern in Massachusettsa

\begin{tabular}{|c|c|c|c|}
\hline & \multicolumn{2}{|c|}{$\begin{array}{l}\text { Percent of } \\
\text { Eligible Cases } \\
(N=775)\end{array}$} & \multirow[t]{4}{*}{$\begin{array}{l}\text { Percent of } \\
\text { Appeals } \\
\text { Completed } \\
(N=103)\end{array}$} \\
\hline No appeal . . . . . . . . & & 72.5 & \\
\hline Appeal withdrawn ... & & 14.3 & \\
\hline Appeal $\ldots \ldots \ldots$ & & 13.2 & \\
\hline Affirmed $\ldots \ldots \ldots$ & 10.7 & & 79 \\
\hline Increased $\ldots \ldots \ldots$ & .2 & & 2 \\
\hline Reduced $\ldots . . .$. & 2.3 & & 19 \\
\hline Total ....... & & 100.0 & 100 \\
\hline
\end{tabular}

This is the overall picture in the two states. Frequency of sentence modification and presumably therefore frequency of appeal appear to be related to at least three characteristics of the case: the severity of the original sentence; whether sentence was imposed after trial or after guilty plea; and in some instances the identity of the sentencing judge. These relationships are discussed in the following sections.

\section{SEVERITY OF THE ORIGINAL SENTENCE}

We know already 47 that roughly three-fourths of all eligible offenders never file an appeal, that some of the remaining one-fourth later withdraw their appeal, with the result that in Massachusetts only 13 percent and in Connecticut only 17 percent of all eligible cases are heard by the division.

Table 5 shows how these various decision points are related to the severity of the original sentence.

In Massachusetts the average sentence for all eligible defendants was 84 months. The cases eventually heard by the division had an average sentence of 142 months, 69 percent above the 84-month average. The average sentence of those who never filed an appeal was 74 months, 12 percent below the average for all offenders.

The situation in Connecticut is similar; the average sentence of all defendants heard by the division is 71 percent above the average. The similarity is the more impressive since the level of prison sentences in the two states differs enormously: the average sentence minimum in

47. From tables 2 and 4. 
TABLE 5

Average Length of Appealed and Modified Sentences

Massachusetts

\begin{tabular}{|c|c|c|c|}
\hline & Percent & $\begin{array}{l}\text { Average } \\
\text { Sentence } \\
\text { Minimum } \\
\text { (Months) }\end{array}$ & $\begin{array}{l}\text { Percent } \\
\text { Below or Above } \\
\text { Average of } \\
84 \text { Months }\end{array}$ \\
\hline $\begin{array}{l}\text { No appeal } \ldots \ldots \ldots \\
\text { Appeal withdrawn } \ldots \ldots \\
\text { Appeal } \ldots \ldots \ldots \ldots\end{array}$ & $\begin{array}{l}73 \\
14 \\
13\end{array}$ & $\begin{array}{r}74 \\
84 \\
142\end{array}$ & $\begin{array}{r}-12 \\
0 \\
+69\end{array}$ \\
\hline $\begin{array}{l}\text { Affirmed } \ldots \ldots \ldots \\
\text { Reduced } \ldots \ldots \ldots\end{array}$ & $\begin{array}{r}10.7 \\
2.3\end{array}$ & $\begin{array}{l}143 \\
133\end{array}$ & $\begin{array}{l}+70 \\
+58\end{array}$ \\
\hline All cases $\ldots \ldots \ldots$ & 100 & 84 & inths \\
\hline
\end{tabular}

Connecticut

\begin{tabular}{|c|c|c|}
\hline Percent & $\begin{array}{c}\text { Average } \\
\text { Sentence } \\
\text { Minimum } \\
\text { (Months) }\end{array}$ & $\begin{array}{c}\text { Percent } \\
\text { Below or Above } \\
\text { Average of } \\
31 \text { Months }\end{array}$ \\
\hline $\begin{array}{r}76 \\
7 \\
17\end{array}$ & $\begin{array}{l}26 \\
39 \\
53\end{array}$ & $\begin{array}{l}-16 \\
+26 \\
+71\end{array}$ \\
\hline $\begin{array}{r}15.7 \\
1.3\end{array}$ & $\begin{array}{l}51 \\
74\end{array}$ & $\begin{array}{r}+65 \\
+139\end{array}$ \\
\hline 100 & 31 & inths \\
\hline
\end{tabular}

Massachusetts is 84 months ( 7 years) as against 31 months (2 years, 7 months) in Connecticut, a ratio of 2.6 to 1 .

Table 6 for Massachusetts and table 7 for Connecticut allow a more precise view of the relationship between the severity of the original sentence and the various decisions in the review process.

\section{TABLE 6}

Massachusetts Rate of Reduction and Appeal by Minimum of Original Sentence

$\begin{array}{cc}\text { Minimum } & \text { Percent of } \\ \text { Sentence } & \text { Eligible Cases } \\ \text { (Months) } & (N=775)\end{array}$

Up to $24^{b} \ldots \ldots$.

$25-36^{\mathrm{b}} \ldots \ldots \ldots$

$37-48 \ldots \ldots \ldots$

$49-60 \ldots \ldots$

61 or more ......

Total .......

$$
\text { Total } \ldots . . . . . .100
$$

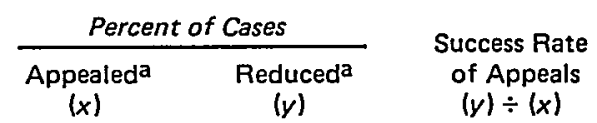

0

$[0.5$

4

4

27
0

0.5

0

0

5

$\underline{\underline{2.3}}$
0

$100] *$

0

0

19

Average $\ldots \ldots \ldots \ldots \ldots \ldots \ldots \ldots, \underline{\underline{13}}$

aof all cases in that sentence group.

bAll defendants used for data in this table received a sentence maximum of at least 30 months; the minimum can be smaller.

*One case, see text infra at note 48 . 
The first column in table 6 gives the distribution of the minimum sentence received by all Massachusetts offenders eligible for review. One-fourth of them $(1 \%+24 \%)$ received sentences up to 3 years, about one-third $(7 \%+25 \%)$ sentences over 3 and up to 5 years, and the remaining 43 percent received minimum sentences of over 5 years. Column (y) reveals for each sentence bracket the proportion of eligible sentences-irrespective of whether they had been appealed-that were reduced by the division. The picture that column (y) reveals for Massachusetts is startling. Except for one single, somewhat out-of-theordinary case, ${ }^{48}$ the Massachusetts division had modified only those sentences where the minimum was over 5 years. The pattern is so clear that it amounts to tacit rulemaking, albeit a rule that, if made explicit, might be regarded as violating the statute that makes all sentences with a possible maximum of $2 \frac{1}{2}$ years or more eligible for review. In any event, as column ( $\mathrm{x}$ ) shows, this unstated rule appears to be well understood by the potential applicants. No applicants (again with the one exception) applied for review who had received a prison sentence with a minimum of 3 years or less. And of the offenders who received minimum sentences of over 3 and up to 5 years, only 4 percent applied for review. In the over-5-year group, 27 percent of the offenders appealed, and 19 percent of the appeals were successful; thus 5 percent of all offenders with sentences over 5 years received reductions.

The picture for Connecticut is in many respects similar.

TABLE 7

Connecticut Rate of Reduction and Appeal by Minimum of Original Sentence

\begin{tabular}{|c|c|c|c|c|}
\hline \multirow{2}{*}{$\begin{array}{l}\text { Minimum } \\
\text { Sentence } \\
\text { (Months) }\end{array}$} & \multirow{2}{*}{$\begin{array}{l}\text { Percent of } \\
\text { Eligible Cases } \\
(N=918)\end{array}$} & \multicolumn{2}{|c|}{ Percent of Cases } & \multirow{2}{*}{$\begin{array}{c}\text { Success Rate } \\
\text { of Appeals } \\
(y) \div(x)\end{array}$} \\
\hline & & $\begin{array}{l}\text { Appealed }{ }^{a} \\
(x)\end{array}$ & $\begin{array}{l}\text { Reduceda } \\
\qquad(y)\end{array}$ & \\
\hline Up to $24 \ldots \ldots$ & 53 & 6 & * & 3 \\
\hline $25 \cdot 36 \ldots \ldots \ldots$ & 13 & 26 & 0 & 0 \\
\hline $37-48 \quad \ldots \ldots \ldots$ & 5 & 31 & 8 & 26 \\
\hline $49-60 \ldots \ldots \ldots$ & 7 & 37 & 2 & 5 \\
\hline 61 or more ..... & 22 & 26 & 3 & 12 \\
\hline Total . . . . . & 100 & & & \\
\hline Average $\ldots \ldots \ldots$ & $\ldots \ldots \ldots \ldots$ & 16.9 & 1.2 & 7 \\
\hline
\end{tabular}

48. The exception, in the 25-36-month group, was the one sentence appealed out of the $\mathbf{1 8 6}$ cases, and it resulted in a sentence reduction. The offender was a woman with four children who had been pregnant at the time of the offense. See case 528 in section XI. 
Connecticut, too, has its minimum level below which a sentence is not considered for reduction: practically no sentence under 3 years is ever modified. This limit is lower than in Massachusetts but because of the 'generally lower sentences in Connecticut, it excludes 66 percent of all eligible sentences from consideration, a larger proportion than in Massachusetts.

The gross appeal rate in Connecticut at the sentence levels where reductions occur is of the same magnitude as at the over-5-year level in Massachusetts, generally around 30 percent. Unlike Massachusetts, however, Connecticut also has a substantial appeal rate at the 25-36-month level, and 6 percent of the offenders appeal even at the lowest sentence level although the chances of reduction are practically nil.

\section{SENTENCE IMPOSED AFTER TRIAL AND AFTER GUILTY PLEA}

Often a defendant pleads guilty after some bargain with the prosecutor that may include an agreed-upon sentence recommendation. The judge, of course, is not bound by the prosecutor's recommendation. But if the judge accedes to it, as is often the case, one might say that the defendant had accepted the sentence and therefore is bound by it. This is the view of the Connecticut division. Efforts to have a sentence reduced because it was in fact "no bargain" fail:

The agreement was fairly secured, the plea was voluntary and knowing, and the prosecution kept its bargain with the accused. ${ }^{49}$

The defendant bargained for the sentence he received. He cannot now complain. 50

These sentences [were] a result of plea bargaining and were agreed to by the defendant and his counsel. A request for a lesser sentence is not in order.

The division goes further and will hesitate to modify a sentence which, though not agreed upon, was implied by the plea concluded after negotiation.

The defendant received consideration when he was permitted to plead guilty to robbery in the third degree as he was previously presented on robbery in the first degree... which offense carries a mandatory five year minimum sentence.

It appears that the Connecticut division accepts only sentences for review which were neither explicitly nor implicitly part of the plea

49. Published opinion: State v. Cato, 29 Conn. Supp. 443, 290 A.2d 901 (1972).

50. Unpublished opinion. This quotation and many of those that follow are from opinions not published by the review division; they were taken from division files. Because the opinions are not a matter of public record and contain information on criminal history, they are not cited by name. Whenever a quotation is presented without a citation, it comes from an unpublished opinion. 
bargain. This may happen if the judge does not accept the agreed-upon recommendation, or if a sentence recommendation was not part of the bargain. Mere disregard of the prosecutor's recommendation, however, is no automatic ground for sentence reduction.

A sentencing judge is not required to rubber-stamp a recommendation even if it is an agreed recommendation. He has the discretion to sentence the accused as he sees fit.

For all these reasons there should be fewer sentence reductions and fewer appeals after a plea of guilty than after trial. Furthermore, cases that go to trial involve on the average more serious crimes and therefore fetch more severe sentences. Finally, there is some reason to believe that, even for the same offense, sentences after trial are at times higher than those given after a guilty plea. For all these reasons we should expect a lower rate of sentence reduction and a lower appeal ratio among offenders convicted after a guilty plea. These facts are borne out in table 8 .

TABLE 8

Rate of Sentence Appeal and Reduction by Type of Conviction

Massachusetts (Sentences over 5 Years Only)a

\begin{tabular}{|c|c|c|c|c|}
\hline & & & & \\
\hline & $\begin{array}{r}A \\
\text { Guilt }\end{array}$ & $\begin{array}{l}\text { ter } \\
\text { Plea }\end{array}$ & Afte & Trial \\
\hline No appeal & & 81.0 & & 61.8 \\
\hline Appeal $\ldots \ldots \ldots$. & & 19.0 & & 38.2 \\
\hline Affirmed $\ldots \ldots \ldots$ & 14.0 & & 32.7 & \\
\hline Reduced $\ldots . . .$. & 4.6 & & 5.1 & \\
\hline Total ........ & & 100.0 & & 100.0 \\
\hline Number & & (195) & & (136) \\
\hline
\end{tabular}

Connecticut (Sentences over 3 Years Only) a

\begin{tabular}{|c|c|c|c|c|}
\hline & \multicolumn{4}{|c|}{ Percent } \\
\hline & $\begin{array}{r}\text { A } \\
\text { Guil }\end{array}$ & $\begin{array}{l}\text { ter } \\
\text { Plea }\end{array}$ & Afte & Trial \\
\hline No appeal $\ldots \ldots \ldots$ & & 75.2 & & 48.0 \\
\hline Appeal $\ldots \ldots \ldots$ & & 24.8 & & 52.0 \\
\hline Affirmed ........ & 22.3 & & 44.0 & \\
\hline Reduced ........ & 2.5 & & 8.0 & \\
\hline Total ........ & & 100.0 & & 100.0 \\
\hline Number .......... & & (318) & & (25) \\
\hline
\end{tabular}


In both Massachusetts and Connecticut the rate of sentence appeal after trial is twice as high as after a guilty plea; and in each category the Connecticut rate is higher than the corresponding Massachusetts rate. Normally, appeal rates reflect the likelihood of success. One would expect, therefore, higher reduction rates for sentences after trial. For Massachusetts this is not true: both rates are in the neighborhood of 5 percent. In Connecticut, the success rate after trial is 8 percent, as against 2.5 percent after guilty plea. But the sample of trials there is so small ( 25 cases) that one cannot be sure it is a true result.

There are fewer trials in Connecticut than in Massachusetts, as the following official statistics show. ${ }^{51}$

\section{TABLE 9}

Disposition of Felony Indictments in Massachusetts and Connecticut (Percent)

\begin{tabular}{|c|c|c|c|c|c|c|}
\hline & \multirow[b]{2}{*}{$\begin{array}{c}\text { Dismissals } \\
\text { (1) }\end{array}$} & \multirow[b]{2}{*}{$\begin{array}{c}\text { Guilty } \\
\text { Pleas } \\
\text { (2) }\end{array}$} & \multicolumn{3}{|c|}{ Trials ${ }^{a}$} & \multirow[b]{2}{*}{$\begin{array}{c}\text { Total } \\
\text { Convictions } \\
(2)+(3)\end{array}$} \\
\hline & & & $\begin{array}{l}\text { Convic- } \\
\text { tions } \\
\text { (3) }\end{array}$ & $\begin{array}{l}\text { Acquit- } \\
\text { tals } \\
(4)\end{array}$ & $\begin{array}{l}\text { Total } \\
(3)+(4)\end{array}$ & \\
\hline \multicolumn{7}{|l|}{ Massachusetts } \\
\hline$(N=17,191) \ldots$ & 20.0 & 59.6 & 12.1 & 8.3 & 20.4 & 71.7 \\
\hline Connecticut & & & & & & \\
\hline$(N=3,004) \ldots$ & 21.5 & 74.7 & 2.5 & 1.3 & 3.8 & 77.2 \\
\hline
\end{tabular}

In Massachusetts 20 percent of all felony indictments reach trial; in Connecticut, only 4 percent do. These figures differ from those in table 8 because they include indictments that were dismissed or resulted in acquittal and sentences not eligible for appeal because they fell below the eligibility limit.

Tables 10 and 11 allow a more refined insight into the different reaction of the system toward sentences after trial and after guilty plea by presenting the alternative separately for the various degrees of severity of the original sentence. Table 10 concerns Massachusetts. In that state, of course, we have no policy expressions and are left to infer the policy from the decision pattern. As we already know, the division normally does not modify any sentence that begins with 5 years or less,

51. Figures obtained from official statistics of Connecticut and Massachusetts. A low ratio of trials is a tradition of long standing in the state of Connecticut. A 1955 count revealed 3 jury trials per year per 100,000 population for Connecticut as against 51 in Massachusetts (cf. Harry Kalven, Jr., \& Hans Zeisel, The American Jury 502 (Chicago: University of Chicago Press, 1971). 
hence column $(x)$ has nothing but zeros except for the line that represents sentences over 5 years and the one exceptional case after trial. In that group of high sentences, however, the reduction rate is the same-5 percent-after trial and after guilty plea, even though the appeal rate is twice as high after trial (38\%) as after guilty plea (19\%).

\section{TABLE 10}

Rates of Reduction and Appeal by Severity of Sentence and Type of Conviction in Massachusetts

$\begin{array}{cc}\text { Minimum } & \text { Percent of } \\ \text { Sentence } & \text { Eligible Cases }\end{array}$

(Months)

\begin{tabular}{|c|c|}
\hline \multicolumn{2}{|c|}{ Percent of Cases } \\
\hline $\begin{array}{l}\text { Appealed } \\
(x)\end{array}$ & $\begin{array}{l}\text { Reduced } \\
\text { (y) }\end{array}$ \\
\hline
\end{tabular}

After guilty plea $(N=528)$ :

\begin{tabular}{|c|c|}
\hline Up to $24 \ldots$ & 2 \\
\hline $25-36 \ldots \ldots$ & 30 \\
\hline $37-48 \ldots \ldots$ & 7 \\
\hline $49-60 \ldots$ & 25 \\
\hline 61 and over. & 36 \\
\hline Total & 100 \\
\hline
\end{tabular}

$\underline{\underline{27}} \quad \underline{\underline{27}}$

\begin{tabular}{|c|c|c|c|c|}
\hline $\begin{array}{l}\text { After trial } \\
\qquad(N=226):\end{array}$ & & & & \\
\hline Up to $24 \ldots \ldots$ & 0 & 0 & 0 & 0 \\
\hline $25-36 \ldots \ldots$ & 11 & {$[4$} & 4 & $100] *$ \\
\hline $37.48 \ldots \ldots \ldots$ & 7 & 7 & 0 & 0 \\
\hline $49-60 \ldots \ldots$ & 22 & 12 & 0 & 0 \\
\hline 61 and over .... & 60 & 38 & 5 & 13 \\
\hline Total & 100 & & & \\
\hline
\end{tabular}

Average $\ldots \ldots \ldots \ldots \ldots \ldots \ldots \ldots$

*One case; see table 6. $\stackrel{3.5}{\underline{13}}$

Table 11 presents the Connecticut figures. The surprising aspect of the Connecticut pattern is the division's hesitancy to modify sentences after trial unless the sentences had a minimum of more than 5 years. Trial, as we saw, is in Connecticut the exceptional way of disposing of an indictment, and perhaps there is a feeling in the division that if a defendant-against tradition-insisted on a trial, he must accept the consequences. Such thoughts may be inferred from the following scenario of a case:

Defendant, just before trial, had been offered a nine-month jail term recom- 
mendation by the state's attorney. His codefendant was offered the same deal, took it, and was sentenced accordingly. The defendant went to trial and was convicted of robbery with violence ( $\$ .35$ taken). The state's attorney recommended 5 to 15 years in prison. The judge sentenced him to a 3- to 8-year prison term. The division affirmed.

The appeal rate for convictions after trial is nevertheless considerable at all sentence levels, suggesting that perhaps in a larger sample of trial convictions (the present one contains only 42 cases) we would also find reductions at the lower levels.

\section{TABLE 11}

Rates of Reduction and Appeal by Severity of Sentence and Type of Conviction in Connecticut

$\begin{array}{cc}\text { Minimum } & \text { Percent of } \\ \text { Sentence } & \text { Eligible Cases }\end{array}$

\begin{tabular}{ccc}
\multicolumn{2}{c}{ Percent of Cases } & Success Rate \\
of Appeals \\
$(x)$ & $\begin{array}{c}\text { Reduced } \\
(y)\end{array}$ & $(y) \div(x)$
\end{tabular}

After guilty plea

$$
(N=809) \text { : }
$$

Up to $24 \ldots \ldots . \quad 51$

$25-36 \ldots \ldots \ldots \quad 14$

$37-48 \ldots \ldots \ldots \quad 5$

$49-60 \ldots \ldots .6$

61 and over $\ldots . \quad 23$

Total ..... 100

Average $\ldots \ldots \ldots \ldots \ldots \ldots \ldots \ldots$

After trial

$$
(N=42) \text { : }
$$

Up to $24 \ldots \ldots . \quad 21$

$25-36 \ldots \ldots \ldots$

$37-48 \ldots \ldots \ldots$

$49.60 \ldots \ldots . \quad 12$

61 and over ....

Total ...... 100

$\underline{\underline{1.0}}$

4

0

$\underline{6}$

Average $\ldots \ldots \ldots \ldots \ldots \ldots \ldots$ $\underline{\underline{4.8}} \quad \underline{\underline{\underline{n}}}$

$\begin{array}{rrr}33 & 0 & 0 \\ 62 & 0 & 0 \\ 0 & 0 & 0 \\ 40 & 0 & 0 \\ 61 & 11 & 18\end{array}$

18 *One case; see table 7.

\section{IDENTITY OF THE SENTENCING JUDGE}

Our data carry the suggestion that the sentences of some judges have a greater probability of being reduced than those of other judges. Table 12 records the reduction and appeal rates for the 23 Massachusetts judges in our sample with ten or more cases. 
Only 7 of the 23 judges who had at least ten cases had any of their sentences reduced, but the proportion of reductions varies considerably from judge to judge: 14 percent for Judge No. 12, 7 percent for Judge No. 3, etc.; the other 5 judges have lower rates, and 16 judges had none of their sentences modified. The fact that these rates are distributed unequally does not by itself suggest that some judges are more likely to encounter reductions than others; pure chance will always yield variations. At issue is the magnitude of the variations. There is a standard statistical procedure designed to test whether a distribution such as this significantly differs from what pure chance would have produced. That test suggests that the instant distribution is on the borderline beyond which one would firmly assert that some of these judges have a higher likelihood of being reversed. ${ }^{\mathbf{2}}$

\section{TABLE 12}

Sentence Reduction and Appeal Rate of Massachusetts Judges with 10 or More Cases

\begin{tabular}{|c|c|c|c|c|c|c|}
\hline \multirow{2}{*}{\multicolumn{2}{|c|}{$\begin{array}{l}\text { Judge } \\
\text { No. }\end{array}$}} & \multicolumn{2}{|c|}{ Percent of All Cases } & \multirow[b]{2}{*}{$\begin{array}{l}\text { Judge } \\
\text { No. }\end{array}$} & \multicolumn{2}{|c|}{ Percent of All Cases } \\
\hline & & $\begin{array}{l}\text { Reduction } \\
\text { Rate }\end{array}$ & $\begin{array}{l}\text { Appeal } \\
\text { Rate }\end{array}$ & & $\begin{array}{l}\text { Reduction } \\
\text { Rate }\end{array}$ & $\begin{array}{l}\text { Appeal } \\
\text { Rate }\end{array}$ \\
\hline $1 \mathrm{a}$ & $\ldots \ldots \ldots$ & 1 & 6 & $\ldots \ldots$ & 0 & 13 \\
\hline 2 , & $\ldots \ldots \ldots$ & 0 & 14 & $14^{a} \ldots \ldots \ldots$ & 5 & 16 \\
\hline $3^{\mathbf{a}}$ & $\ldots \ldots \ldots$ & 7 & 35 & $15 \ldots \ldots \ldots$ & 0 & 6 \\
\hline $4^{a}$ & $\ldots \ldots \ldots$ & 0 & 15 & $16^{a} \ldots \ldots \ldots$ & 0 & 0 \\
\hline 5 . & $\ldots \ldots$ & 5 & 5 & $17 \& 18^{b} \quad \ldots$ & 6 & 13 \\
\hline 6 . & $\ldots \ldots \ldots$ & 0 & 0 & $19 a \ldots \ldots$ & 0 & 3 \\
\hline $7 a$ & $\ldots \ldots \ldots$ & 0 & 6 & $20 \ldots \ldots \ldots$ & 0 & 16 \\
\hline $8 a$ & $\ldots \ldots \ldots$ & 0 & 43 & $21 a \ldots \ldots$ & 0 & 11 \\
\hline 9. & $\ldots \ldots \ldots$ & 0 & 7 & $22^{a} \ldots \ldots \ldots$ & 0 & 4 \\
\hline 10 & $\ldots \ldots \ldots$ & 0 & 0 & $23^{a} \ldots \ldots \ldots$ & 5 & 5 \\
\hline 11 & $\ldots \ldots \ldots$ & 0 & 14 & All other judges & & \\
\hline $12^{a}$ & $\ldots \ldots$ & 14 & 20 & combined ... & 9 & 1 \\
\hline
\end{tabular}

at least 20 cases.

bTwo judges had to be coded together; they had a combined total of $\mathbf{5 2}$ cases.

We have, however, additional evidence that encourages us to firmly assert that proposition. If we look at the rates of appeal for these various judges, we find that with the exception of Judge No. 8 , who had no sentence reduced but had 43 percent appealed, the two judgesNos. 12 and 3 -who have the highest reduction rate have also the highest appeal rate. This suggests that these judges are known for their heavier sentences and for that reason are more often appealed. 1969). For modification rates, $x^{2}=30.81, p<.10$; for appeal rates, $x^{2}=89.10, p<.001$. 
IX. SIZE OF SENTENCE REDUCTIONS

Both Connecticut and Massachusetts give indeterminate sentences by setting both the minimum and the maximum. As a rule, both limits are reduced but occasionally only the minimum or the maximum sentence is modified. On the average, the size of the reduction in both states is about one-third of the original sentence, for both the sentence maximum and the minimum. Tables 13 and 14 give the detailed picture.

TABLE 13

Size of Sentence Reductions in Connecticuta

\begin{tabular}{|c|c|c|c|c|c|c|}
\hline \multirow[b]{2}{*}{ Case No. } & \multicolumn{3}{|c|}{ Minimum } & \multicolumn{3}{|c|}{ Maximum } \\
\hline & From & To & $\begin{array}{c}\text { Percent } \\
\text { Reduction }\end{array}$ & From & To & $\begin{array}{c}\text { Percent } \\
\text { Reduction }\end{array}$ \\
\hline $176 \ldots$ & 4 & 3 & 25 & 8 & 6 & 25 \\
\hline $175 \ldots$ & - & - & - & 5 & 3 & 40 \\
\hline $182 \ldots$ & 6 & 6 & 0 & 25 & 10 & 60 \\
\hline $184 \ldots$ & 10 & 10 & 0 & 65 & 37 & 43 \\
\hline $186 \ldots$ & 5 & 4 & 20 & 10 & 10 & 0 \\
\hline $187 \ldots$ & 10 & 5 & 50 & 20 & 10 & 50 \\
\hline $210 \ldots$ & 9 & 7 & 22 & 10 & 10 & 0 \\
\hline $211 \ldots$ & 9 & 8 & 11 & 18 & 16 & 11 \\
\hline $317 \ldots$ & 2.5 & 1.5 & 40 & 5 & 3 & 40 \\
\hline $181^{\circ} \ldots$ & 4 & 2 & 50 & 7 & 6 & 16 \\
\hline $539 \ldots$ & 2 & 1 & 50 & 5 & 2 & 60 \\
\hline $535 \ldots$ & 4 & 3 & 25 & 10 & 6 & 40 \\
\hline $284 \ldots \ldots$ & 10 & 8 & 20 & 14 & 12 & 16 \\
\hline $285 \ldots$ & 8 & 5 & 37 & 15 & 15 & 0 \\
\hline $149 \ldots$ & 5 & 2 & 60 & 10 & 5 & 50 \\
\hline $177 \ldots$ & 6.5 & 3.5 & 42 & 9 & 7 & 22 \\
\hline $178 \ldots$ & 3.5 & 2.5 & 29 & 7 & 5 & 29 \\
\hline $213 \ldots$ & - & - & - & 3 & 2 & 33 \\
\hline \multicolumn{7}{|c|}{ Average reduction $\ldots \ldots \ldots 30 \ldots \ldots$} \\
\hline
\end{tabular}


TABLE 14

Size of Sentence Reductions in Massachusetts ${ }^{a}$

\begin{tabular}{|c|c|c|c|c|c|c|}
\hline \multirow[b]{2}{*}{ Case.No. } & \multicolumn{3}{|c|}{ Minimum } & \multicolumn{3}{|c|}{ Maximum } \\
\hline & From & To & $\begin{array}{c}\text { Percent } \\
\text { Reduction }\end{array}$ & From & To & $\begin{array}{l}\text { Percent } \\
\text { Reduction }\end{array}$ \\
\hline & 10 & 7 & 30 & 20 & 20 & 0 \\
\hline 16 & 10 & 7 & 30 & 20 & 20 & 0 \\
\hline 302 & 7.5 & 5 & 33 & 13 & 10 & 23 \\
\hline 307 & 8 & 5 & 38 & 10 & 7 & 30 \\
\hline $314 \ldots \ldots$ & 9 & 2.5 & 73 & 10 & 2.5 & 75 \\
\hline $354 \ldots \ldots$ & 25 & 10 & 60 & 35 & 20 & 47 \\
\hline $390 \ldots$ & 12 & 9 & 25 & 20 & 20 & 0 \\
\hline $392 \ldots \ldots$ & 5 & 2.5 & 50 & 7 & 2.5 & 65 \\
\hline $394 \ldots \ldots$ & 4 & 2 & 50 & 7 & 2 & 69 \\
\hline $423 \ldots$ & 18 & 15 & 17 & 20 & 20 & 0 \\
\hline $435 \ldots$ & 10 & 4 & 60 & 20 & 10 & 50 \\
\hline $491 \ldots$ & 7 & 4 & 47 & 12 & 12 & 0 \\
\hline $521 \ldots$ & 9 & 9 & 0 & 15 & 10 & 33 \\
\hline $484^{b} \ldots$ & 5 & 4 & 20 & 10 & 5 & 50 \\
\hline $465^{b} \ldots$ & 10 & 9 & 9 & 20 & 10 & 50 \\
\hline
\end{tabular}

Average reduction $\ldots \ldots \ldots, \quad 36 \quad \ldots \ldots \ldots$

aFive sentence reductions are omitted from this table: one sentence of 3-10 years was suspended; in a second instance, two codefendants who had received 2 consecutive life sentences had one of the sentences changed to 8-10 years; in the remaining reductions one codefendant who had received consecutive life and 7-10-year sentences had the sentences made concurrent and the other codefendant had consecutive 4-5- and 7-10-year sentences made concurrent.

boncurrent sentences.

We now have reached a crucial stage in our investigation, namely the search for the reasons the review board modified or did not modify the sentences in these cases. The next three sections present our findings.

\section{REASONS FOR REDUCTIONS: CONNECTICUT}

Our search for reasons in the cases in which the Connecticut Sentence Review Division (SRD) reviewed the sentence was aided to some extent by the reasons stated in the opinions. We present herein thumbnail sketches of these opinions grouped in five categories. In table 15 we offer a summary of the reasons given by the division in these 24 cases (see p. 917 infra). ${ }^{53}$

53. These cases include all sentence modifications in Connecticut for 1962,1967 , and 1972. 
(1) Sentence Exceeded Statutory Limit

Case 175

A 17-year-old boy had pleaded guilty to being a youthful offender. He had sold drugs-heroin and marijuana-to fellow students who subsequently became ill in school. There had been a public uproar and the judge sentenced the defendant to an indefinite term in the reformatory.

The SRD said that in principle the sentence was not too severe, but it noted that the law allows a court to commit a youthful offender only "for a period not to exceed three years." The sentence was accordingly modified.

\section{Case 153}

The defendant, a 19-year-old boy without any record, pleaded guilty to a charge of breach of the peace, which had resulted from an altercation with the police. The D.A. had recommended a 3-month suspended sentence, but the judge imposed an indefinite sentence (maximum 2 years) at the reformatory.

The division noted that the offense was a class-B misdemeanor, which allows a maximum sentence of 6 months. Inasmuch as the defendant by the time he came before the SRD had served over $5 \frac{1 / 2}{2}$ months, the division changed the sentence to "time served."

\section{(2) Sentence Out of Line with Codefendants'}

Case 211

Defendant and two codefendants, one of them his brother, had held up a bank at gun point. The defendant fired two shots, said, "We're not fooling around," and the codefendant meanwhile collected the money. The loot was recovered after a chase. All pleaded guilty to robbery, 1st degree. The state's attorney had recommended 8-16 years for each defendant. One codefendant received that sentence; the other codefendant, who had given information to the state, received a sentence of 6-12 years; the defendant a sentence of 9-18 years, after the state's attorney changed his recommendation to this term.

At the SRD hearing, the defendant argued that he and his brother should be treated equally (8-16 years). The state's attorney agreed and the SRD so ordered.

\section{Case $112^{54}$}

Some codefendants do not provide automatic standards for comparison. The board will at times distinguish with great care. The defendant, 18 years old, with two codefendants had stolen some tires and wheels from a car dealer. The tires were recovered from a codefendant. All three defendants pleaded guilty to theft; the defendant was sentenced to the state reformatory for an indefinite term while his two codefendants were given suspended sentences of 6 months in jail. It seems the distinction was made because the defendant had a record of a suspended jail sentence in 1965 for injury to personal property and breaking and entering a dwelling in the daytime, and was on probation when the present offense was committed. 
The SRD, however, noted several circumstances that, in its opinion, should here counterbalance the record: "Although it is not within the province of this Division to protect the collateral constitutional rights of a defendant, the complete lack of any statement on behalf of this defendant [who appeared without counsel] when the other two co-defendants, who received less harsh sentences were represented by counsel, make it difficult for this Division to adequately review the action of the sentencing court.

"We particularly note that the theft was for the benefit of a co-defendant who received a less harsh sentence. We also note that the defendant showed remorse when given an opportunity to speak, saying, 'I'm sorry [for] what happened. I went down and turned myself in. That's about it.' The defendant must be given the benefit of all these mitigating circumstances."

The division ordered that the trial court sentence be suspended as the defendant at the time of the hearing had spent almost five months in prison.

\section{Case 176}

The 21-year-old defendant pleaded guilty to robbery with violence and to theft with two friends after having stolen a car and held up a gasoline station. The case against the two friends was nolled because both were doing a lengthy prison term at the time for another offense. The defendant was sentenced to 4-8 years.

The SRD reduced the sentence to 3-6 years: "This was the defendant's first felony offense. In addition Charles Marsh and Ronald Marsh did not receive any punishment for their participation in the holdup. Therefore the division believes that the four to eight sentence is a little high."

\section{Case 539}

The 19-year-old defendant had pleaded guilty to a count of issuing a bad check and to burglary three. He had stolen and forged an $\$ 89$ check and with two other young men burglarized a moving company, from which they stoleand later cashed-two checks worth $\$ 140$. One of the codefendants, who had no prior record, received a suspended sentence. The defendant, who had been incarcerated previously for less than a year, had been on parole at the time of his arrest, and had altogether 9 adult convictions, received a 2-5-year sentence. The second codefendant, however, who, as the SRD notes, "had a prior record similar to that of the applicant," received a 1-year jail sentence.

The division found, therefore, the 2-5-year sentence "so disproportionate to the similarly situated codefendant as to be unduly harsh" and reduced the sentence to 1-2 years.

\section{Case $863^{55}$}

The defendant was a 20-year-old boy, a high school dropout and unskilled worker who nevertheless had a somewhat stable work record. He had taken part in youth group vandalism-burglary at two unguarded homes.

The division's review weighed his degree of participation against that of his codefendants who had received sentences ranging from suspension to incarceration. The division noted that the defendant participated only twice in 
these burglaries, which had extended over a period of three months. Only once did he enter the house. On his record was only a breach of the peace violation; he had a good school record and was a church member. In consideration of the sentences his codefendants received, his sentence of $1 \frac{1 / 2-3}{\text { years }}$ was modified to 6 months in jail, with an additional probation for 24 months.

Case 499

The defendant, together with another young woman, pleaded guilty to the charge of obtaining money under false pretenses and of subsequent breach of the peace. Both women had similar prior records-several adult convictionsand both received the same sentence of 1-3 years. The codefendant's lawyers moved later that the sentence be reduced, and a judge in the trial court (apparently not the trial judge) suspended the rest of the sentence and put the codefendant on parole. When the defendant made a similar motion to that judge, he realized that he had had no right to reduce a sentence and refused this time.

The SRD thought it its duty to equalize the two sentences and ordered that the defendant's sentence also be suspended with parole. It adds, somewhat superfluously: "Since the Division cannot conceive that this situation will ever come up again ... it will not consider its decision in this case as precedent."

\section{Case 213}

The defendant, age 17, was in high school at the time of the offense. He pleaded guilty to 11 counts of burglary and claimed that he committed the offenses to get money so his friend could pay for his car. The defendant was sentenced to an indefinite to 3-year reformatory sentence, while his codefendants received probation and suspended sentences.

The division reduced his sentence to a 2-year maximum but did not suspend it, pointing out that the defendant lacked the stable family environment of his codefendants.

(3) Adult Would Have Received Less

Case $120^{56}$

Defendant was an 18-year-old boy, raised by a relative, a high school dropout with a very unstable work history and 2 prior adult convictions for property crimes. In the instant case, defendant pleaded guilty to 1 count of larceny for looting several 7-Up machines of not more than $\$ 15$ from any one machine. He was sentenced to a maximum of 2 years in the reformatory.

Upon review, defendant's sentence was suspended to the 5 months he had already served. His codefendant's sentence had been likewise suspended on review. The division considered the minor nature of the charge and the fact that an adult if convicted of that charge could have received (by statute) no more than a 4-month sentence.

56. State v. Lytwyn, 27 Conn. Supp. 78, 230 A.2d 40 (1967). 


\section{(4) Events that Superseded Trial}

\section{Case 187}

The defendant, a drug addict, had, at age 22, a record of 21 adult convictions: 9 or more burglary convictions, 7 felony convictions, and 5 arrests without convictions. He had previously been incarcerated. He pleaded guilty to 10 counts of burglary and to being a habitual offender, which allows the sentence to be doubled.

In this unusual case, the division had before it a letter from the sentencing judge asking that the sentence be changed: "In thinking about the sentence afterwards, I have come to believe that it was too severe and that a concurrent sentence in Docket No. 18752, for an effective term of 5 to 10 years, would be fairer under all the circumstances." The SRD accepted the recommendation. The defendant had originally been sentenced to 10-20 years; the division, upon the trial judge's recommendation, cut the sentence in half.

\section{Case $753^{57}$}

The defendant in this case was a 17-year-old sentenced to an indefinite sentence in the reformatory, serving a maximum possible time of 2 years for willful injury to private property. He was accused by his landlord of causing $\$ 125$ damage to furniture in the apartment he rented. He had already paid $\$ 70$ in restitution payments. The defendant had a record of 5 adult convictions, including prior incarceration. He pleaded guilty to the present offense.

Upon review, the division reduced the sentence to 3 months and suspended it, noting that the sentencing judge had not been informed about the nature and extent of the damage: "The events constituting the offense available before the Division prove to be more in the nature of hard usage and unsanitary housekeeping, the most serious damage being a cut in the upholstery of a divan. If these facts had been brought to the attention of the court, it seems reasonably probable that it would not have considered the sentence it imposed, as such a penalty is disproportionate to the injury sustained."

\section{(5) Sentence Too Severe}

\section{Case $149^{58}$}

The defendant, age 23, with no prior record of any kind, had gone on a spree of motel hold-ups with a toy pistol. Nobody was ever hurt. He pleaded guilty to several counts of robbery and was sentenced to $5-10$ years. As a child he had been in a concentration camp; he had an excellent scholastic record and stable employment as a skilled engineer.

The division noted that he had "a history of hardship, valor, and brilliant achievement," except for the crime spree. "His prior record is the only basis for the decision of the board that his sentence should be modified." It was: $2-5$ years.

57. State v. Wallick, 27 Conn. Supp. 387, 239 A.2d 544 (1968).

58. State v. Malolepszy, 24 Conn. Supp. 304, 190 A.2d 231 (1963). 


\section{Case 181}

While on escape from jail, defendant stole a car and, when captured, pleaded guilty to one count each of escape and theft of a motor vehicle. He was sentenced for these offenses to 4-7 years (concurrent with previous sentence of 1-2 years) out of a possible maximum of 20 . Defendant is 21 years old, single, a semi-skilled worker with a somewhat unstable work record. At the time of the offense, defendant was on drugs. His prior record included 9 adult convictions for property crimes, 2 for car theft, and 7 arrests without convictions.

Upon review, the division reduced the sentence to 1-3 years, to run consecutive to the previous sentence, thus producing a sentence, in effect, of 2-6 years. By way of explanation, the division noted that the sentences for theft and escape "were higher than they should be."

\section{Case 182}

Defendant was convicted by a jury of four counts of possession and sale of heroin. He was given a sentence of 6-25 years. He was 22 years old, a high school dropout, and an unskilled worker with an unstable work history. His prior record consisted of 2 juvenile and 6 adult convictions, 4 of which were felony convictions, some of them for the same offense as in the instant case. None of the earlier convictions resulted in incarceration.

When the sentence was reviewed by the SRD, the minimum was not reduced, but the maximum sentence was reduced to 10 years because the division found the sentence "too severe when compared to others convicted of the same offense and with similar histories."

Case 184

Defendant had pleaded guilty to three counts of rape of old women, a count of armed robbery, and a count of burglary with violence. Together, the consecutive sentences amounted to a sentence of 10-65 years. The division is concerned with the extraordinarily high maximum sentence. It notes that all these crimes had been committed during a 9-month period during which the defendant suffered from a serious mental problem and disturbances.

Citing the ABA Standards for Sentencing (that 25 years should be the outside limit for accomplishing rehabilitation), the SRD compromised and reduced the sentence to 10-37 years. In its view, a 65-year maximum was "too long and severe to accomplish the purpose and objectives of sentencing." But the division thought that the time had not yet come to throw the prison key away for this defendant.

\section{Case 317}

A furniture store was broken into. Defendant pleaded guilty to one count each of burglary three and 2 counts of larceny and was sentenced to $2 \frac{1 / 2-5}{2}$ years in the reformatory. He is a 19-year-old high school dropout and unskilled worker. He had one prior adult misdemeanor conviction and four prior arrests without convictions, but no prior incarcerations.

Upon review the SRD reduced his sentence to $11 / 2-3$ years, noting the defendant's minor record, and concluded: "While it appears that the defendant does need some strict supervision, it is the belief of the division that the term given was too long, considering all the circumstances." 


\section{Case 284}

The defendant was a 24-year-old man, who had been living with a woman for several weeks, when she moved out of the apartment, leaving him a note saying that she was leaving for good. After drinking almost two quarts of gin, he went to her home and killed her with two shots from his pistol. He had no prior record, pleaded guilty to manslaughter, and was sentenced to 10-14 years.

The SRD noted: "The presentence report describes the defendant as a hard working, congenial, nonaggressive person without any prior tendency toward violence and without any arrests or prior record. The state's attorney recommended a higher minimum than that imposed by the court. The defendant has been truly penitent for the wrong he had wrought. At the time of his sentencing, he stated: 'I never meant to hurt anybody. I don't know what happened, what I was thinking but I'm sorry. Please have some mercy on me, that's all.' Pending his arraignment and while the accused was at the state jail, he aided the authorities by helping to quell a riot and saved some guards from bodily harm." Then follows this statement: "The SRD feels the sentence somewhat severe." The sentence was reduced to 8-12 years.

\section{Case 285}

The defendant's wife, mother of his three children, from whom he was separated at the time of the crime, was beaten by a pimp who had a long criminal record and was coerced into prostitution. Defendant insisted that his wife report the incident to the police, which she did. Whereupon the pimp threatened the woman, demanding that the charges be dropped. Defendant took a gun and killed the man. He was indicted for murder and pleaded guilty to manslaughter; he was sentenced to 8-15 years.

The division noted that the offense was committed "during a period of smoldering agony and seething turmoil over the treatment his wife had received at the hands of the decedent.... Under all the circumstances of this case, the division concludes that sentencing goals would be achieved by less severe sentencing" and reduced the minimum sentence from 8 to 5 years.

\section{Case 210}

A 9-10-year sentence for several counts of selling heroin was reduced to 7-10 years. The reasons: "The sentence was within the legal limits. However, it is slightly high when compared with sentences recently sustained by this division on similar matters arising in the Willimantic and Waterbury areas. The Division has the obligation to bring sentences into line so that the defendants concerned will feel that they have been treated fairly."

\section{Case $168^{59}$}

The defendant is a 16-year-old boy living with both parents and still in high school, who, while drinking and driving recklessly, struck a car and killed one passenger. He had no record of any kind, pleaded no contest, and was sentenced to the reformatory for 9 months, to be suspended after 6 months had been served. 
Upon review, his sentence was terminated at 4 months. The division decided that since the defendant had a favorable background and seemed unilikely to commit any further offenses, a reformatory sentence was unnecessary.

\section{Case 535}

The 32-year-old defendant pleaded guilty to two counts of sexual contacts in the third degree and to one count of risk of injury. The acts were committed on his stepdaughters, aged 15 and 17 . The sentence was 4-10 years.

Upon review, his sentence was reduced to 3-6 years. The division took into account the fact that the defendant had lost his job and family while the case was being prosecured and the fact that his wife and daughters had tried to withdraw the complaint against him. The division, gratuitously, it seems, noted: "For these acts the defendant deserves to be punished. The problem obviously is to tailor the punishment both to the crime and the individual involved."

\section{Case 186}

The defendant, age 26 , married, with two dependents, pleaded guilty to 3 counts of burglary two and 4 counts of burglary three. He was arrested in the house he was burglarizing and later confessed to an additional 22 burglaries. He had never been incarcerated but had a record of 4 felony convictions. His original sentence was 5-10 years.

In reducing the minimum to 4 years, the division said that the sentence was a "little high under the circumstances."

Case 177

The defendant, age 20 , pleaded guilty to 5 counts of burglary three and 2 counts of larceny two. He had 2 felony convictions and previous periods of incarceration for between $I$ and 5 years. His record indicated a drug problem. The defendant was sentenced to $61 / 2-9$ years in prison.

Upon review, the division reduced the sentence to $3 \frac{1 / 2-7}{\text { years but gave no }}$ specific reason for the reduction.

Table 15 gives the reason statistics as summarized from the caseby-case analysis.

The reasons in categories (1) through (4) differ in kind from the reasons in category (5). They provide genuine, complete explanations as to why sentence was reduced. But for the presence of the reason, the sentence would have been affirmed. These reasons at least suggest that any sentence falling into one of these categories would as a rule be reduced.

The cases in category (1) suggest the rule that codefendants who participated in the crime to the same degree, provided there are no significant differences in their personal backgrounds, receive the same sentence. Only if the degree of participation differs significantly or if 


\section{TABLE 15}

Reasons Given for Sentence Reductions in Connecticut Case Nos. No. Percent

1. Judge exceeded statutory limit

2. Out of line with sentence of codefendants

3. Adult would have received less

4. Events that superseded trial

5. Sentence "too severe," for a variety of "reasons"
175,153

$211,112,176$,

$539,863,499$

213

120

187,753

$149,181,182$,

$184,317,284$,

$285,210,168$.

$535,186,177$

Total $\ldots \ldots \ldots \ldots \ldots$

(2) 8.3

(7) 29.2

(1) 4.2

(2) 8.3

(12) $\quad 50.0$

(24) $\overline{100.0}$

other differences obtain, can a different sentence be justified. Here, for instance, is one such case:

[N] one of the codefendants had a previous poor record with respect to probation. They were thus entitled to claim an opportunity to show that they could benefit from a suspended sentence and probation. The defendant, on the other hand, had previously had the same opportunity with a prior offense but had not made anything of the opportunity. The codefendants were entitled to the same chance that she had had, and the reason for giving them that chance was no longer applicable to her.

The distinction between codefendants may also arise, as we have seen, if one codefendant had accepted a plea offer while the other defendant, who had rejected it, received after trial a higher sentence; the division affirmed.

$\mathrm{Be}$ that as it may, cases with codefendants have a much better chance of sentence reduction than other cases and also produce a considerably higher rate of appeal.

TABLE 16

Rate of Sentence Reduction and Appeal in Cases with and Without Codefendants (Percent)

\begin{tabular}{lccccc} 
& \multicolumn{2}{c}{ Massachusetts } & & \multicolumn{2}{c}{ Connecticut } \\
\cline { 2 - 4 } & With & Without & & With & Without \\
Reduction ... & 11 & 1 & 4 & 1 \\
Appeal ..... & 38 & 9 & 70 & 22
\end{tabular}


The reasons in category (5) of table 15 provide at best an incomplete explanation. The mere citing of mitigating circumstances does not explain why the sentence was modified. Nor do these reasons establish any rules identifying the types of cases that would be subject to sentence reduction. The part of the reason clearly left out in these opinions is the explicit statement of a standard, at least intuitively experienced by the division, from which the sentence under appeal deviated too far.

We will have more to say about this problem in section XIII infra, where we try to assess the general value of stated reasons in sentencing decisions.

\section{REASONS FOR REDUCTIONS: MASSACHUSETTS}

The Massachusetts Review Board does not give reasons for its decisions; we were, therefore, limited to an effort to infer these reasons. There follows a brief summary of the twenty cases in our sample in which the division reduced the sentences; each description is supplemented by a list of the mitigating circumstances we could detect. ${ }^{60}$

Case 016

Defendant is a 17-year-old boy, a drug user, with 4 juvenile convictions and 3 adult convictions. Along with three codefendants, he pleaded guilty to robbery charges for which some codefendants received similar sentences (see case 005 ) and some lighter sentences. This defendant was convicted on 6 counts of armed robbery and was sentenced to $10-20$ years. The sentence was reduced upon review to 7-20 years.

\section{Mitigating: \\ -codefendant received lesser sentence -defendant's age}

Case 005

This defendant is one of the codefendants of case 016. Their circumstances are similar. Defendant in this case is 15 years old, with 9 other convictions, 3 for the same offense as in this case, having a record of prior incarceration and a record as a heroin user. He pleaded guilty to 4 counts of unarmed robbery (purse snatching) and 3 counts of armed robbery. He received 10-20 years, which was reduced to 7-20 years.

Mitigating:

-codefendant received lighter sentence

-defendant's age

60. None of the Massachusetts cases in sections XI and XII are cited by name. The descriptions of the cases include information on criminal history, and the Massachusetts Criminal History Systems Board does not permit such information to be made public. 
Case 521

Defendant, along with two codefendants, pleaded guilty to one charge of armed robbery and one count of rape. He was 18 years old, single, with 4 prior juvenile convictions and 1 adult felony conviction, and a prison record. He received two concurrent sentences of 9-15 years. One codefendant got a lighter sentence and one a heavier sentence. Upon review, one sentence was changed to 9-10 years, to run concurrently with the 9-15-year sentence.

Mitigating:

- codefendant received lesser sentence

-defendant's age

Case 491

A 33-year-old man, separated from his wife, pleaded guilty to one charge of incest with his 13-year-old daughter. He had 3 prior adult convictions, including felony convictions, and a prior prison record. The original sentence was 7-12 years. Upon review, his sentence was reduced to 4-12 years. The wife had a nervous breakdown. No information is provided on the daughter's state of mind. The defendant appeared very anxious and had emphysema.

$$
\begin{aligned}
& \text { Mitigating: } \\
& \text {-defendant's bealth }
\end{aligned}
$$

\section{Case 302}

Defendant was a 26-year-old man, separated from his wife, who had been a heroin user. He was found guilty by a jury of one count of breaking and entering with intent to put in fear and commit a felony and one count of assault and battery with a deadly weapon. He had 6 juvenile convictions and 14 prior adult convictions, 3 for the same offense. His original sentence was 71/2-13 years. The division reduced it to $5-10$ years.

$$
\begin{aligned}
& \text { Mitigating: } \\
& \text { - codefendant received lighter sentence } \\
& \text {-letters of support from correction officers, } \\
& \text { estranged wife, coworkers, and Black } \\
& \text { Muslims }
\end{aligned}
$$

\section{Case 307}

Defendant was a 43-year-old man, found guilty by a jury of possession of narcotics with intent to sell. There was some evidence that he had a steady business in narcotics. He had 7 adult convictions, 2 for the same offense, but no prior incarceration. His sentence of 8-10 years was reduced to 5-7 years.

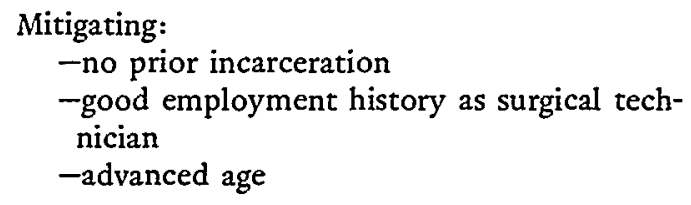

\section{Case 314}

Defendant was a 34-year-old Puerto Rican with no criminal record, charged with assault and battery with a deadly weapon for slashing a woman with a 
knife when she insulted him with racial slurs. The woman's companion brought out a gun, whereupon the defendant tried to deflect it. At this point, it fired and killed the offender's brother. The offender began to beat the woman with a flatiron. She was later further beaten by some other person and run over by an automobile. The incidents have left the woman in a wheelchair and with a speech defect.

The defendant was convicted by a jury and sentenced to 9-10 years. Upon review, the SRD reduced the minimum sentence to $2 \frac{1}{2}$ years.

$$
\begin{aligned}
& \text { Mitigating: } \\
& \text { - no prior record whatsoever } \\
& \text { - married, five children } \\
& \text {-acted on severe provocation and later } \\
& \text { anger over his brother's death } \\
& \text {-brother's death was punishment }
\end{aligned}
$$

\section{Case 354}

Defendant, 23 years old, pleaded guilty to one count of rape. He had 6 prior convictions, at least one for a felony. He had approached his 22-year-old victim on the street, threatened her, and then raped her in a parking garage. Throughout the rape, defendant giggled and laughed, although the psychiatric report indicated no evidence of psychosis in the defendant. Defendant was sentenced to 25-35 years. Upon review, sentence was reduced to 10-20 years.

$$
\begin{aligned}
& \text { Mitigating: } \\
& \text {-reduced mental capacity (notwithstanding } \\
& \text { contrary psychiatric report) }
\end{aligned}
$$

Case 390

Defendant, 29 years old, was convicted by a jury of one count of rape. He had a prior arrest record but no convictions. The original sentence was 12-20 years and was reduced by the division to $9-20$ years.

$$
\begin{aligned}
& \text { Mitigating: } \\
& \text {-no prior convictions }
\end{aligned}
$$

Case 392

Defendant, 26 years old, was found guilty by a jury of possession of a controlled substance with intent to sell. Sentence was 5-7 years. Upon review it was reduced to $2 \frac{1 / 2}{2}$ years in the House of Corrections.

$$
\text { Mitigating: -none }
$$

\section{Case 394}

Defendant, 36 years old, was convicted by a jury of assault and battery with a deadly weapon. He had 1 prior adult felony conviction and a period of incarceration. He received a 4-7 year sentence, which was reduced to 2 years in the House of Corrections.

$$
\begin{aligned}
& \text { Mitigating: } \\
& \text {-history of seizures } \\
& \text {-honorable military discharge } \\
& \text {-very low I.Q. }
\end{aligned}
$$


Case 423

Defendant, single, 20 years old, pleaded guilty to one count of manslaughter and one count of armed robbery. While on escape from the House of Corrections he committed a robbery with a gun, was chased in his car, and had an accident, which killed one and injured seven. He had prior convictions, both juvenile and adult, 1 for manslaughter. He was also a heroin addict. The original sentence of $18-20$ years was reduced to $15-20$ years.

$$
\text { Mitigating: -none }
$$

\section{Case 153}

This defendant is a codefendant of case 152 infra, found guilty of the same offenses of armed robbery and assault with intent to rob. Defendant, married, lived in a commune and was a member of the Black Muslims. He was serving a 4-5 year sentence and in this case received a 7-10 year consecutive sentence. Upon review it was changed to run concurrently with his previous sentence, as was his codefendant's sentence in case 152.

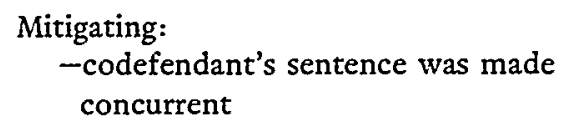

\section{Case 350}

Defendant, 18 years old, black, was found guilty by a jury of 1 count of rape and 1 count of armed robbery. He had 2 prior juvenile convictions and no prior prison record.

With two other men, he had attacked the victim in her home. She was a 32-year-old white woman, not known to the defendant. She was threatened and kicked as well as raped. Defendant and codefendant, case 351, received life sentences on both charges, to be served consecutively. Upon review, the life sentence for armed robbery was reduced to 8-10 years; the other life sentence remained.

$$
\text { Mitigating: -none }
$$

\section{Case 351}

Defendant is the codefendant of case 350 . He is a 20 -year-old black, with 2 prior adult convictions, 1 for a felony. His charges, sentences, and sentence modifications were the same as case 350 .

$$
\text { Mitigating: -none }
$$

\section{Case 465}

Defendant, 19 years old, pleaded guilty to 1 count of armed assault with intent to commit murder and 1 count of assault and battery with a deadly weapon. During a period of racial tension, defendant fired a rifle into a crowd, yelling, "I'm going to get me a nigger." He hit a child, but the child survived. Defendant was sentenced to $10-20$ years on the first count and 10-20 years on the second count, to run concurrently. The second sentence was reduced to 9-10 years, to run concurrently.

Mitigating: - none 


\section{Case 484}

Defendant, 23 years old, married, with four dependents, was charged with multiple kidnapings and rapes at gunpoint or knifepoint. $\mathrm{He}$ was allowed to plead guilty to one charge of rape and one count of assault with a deadly weapon. He had 12 prior adult convictions. He was sentenced to 10-20 years on the rape charge and 5-10 years (concurrent) for the assault. Upon review, the rape sentence was left unchanged; the assault sentence was reduced to 4-5 years, to run concurrently with the rape sentence.

$$
\begin{aligned}
& \text { Mitigating: } \\
& \text {-stable employment record } \\
& \text {-honorable military discharge } \\
& \text {-four dependents }
\end{aligned}
$$

\section{Case 528}

Defendant, a 38-year-old woman, separated from her husband, with four dependents, had no prior record at all when she was charged with murder. She was quarreling with some other women when a man attempted to separate them. She lunged at him with a knife and he was killed. Defendant was pregnant at the time. She was found guilty at a jury trial of manslaughter and assault and battery with a deadly weapon. Sentence was 3-10 years. The sentence was suspended by the review division.

$$
\begin{aligned}
& \text { Mitigating: } \\
& \text {-woman with four dependents } \\
& \text {-pregnant at time }
\end{aligned}
$$

\section{Case 435}

Defendant, 26 years old, divorced, had a record of 5 prior adult convictions and a prison record. Defendant was indicted for murder when, while at target practice, he turned, fired on someone he did not know, and killed him. After the shooting, he turned himself in. He pleaded guilty to 1 count of manslaughter and 1 count of assault and battery with a deadly weapon. His original sentence of $12-20$ years was reduced to $4-10$ years.

$$
\begin{aligned}
& \text { Mitigating: } \\
& \text {-prior record showed no violent crimes } \\
& \text {-no conceivable motive or malice } \\
& \text {-turned himself in }
\end{aligned}
$$

\section{Case 152}

Defendant, along with two codefendants (case 153 supra) was convicted after jury trial of armed robbery and assault with intent to rob. He had already been convicted (with one of the same codefendants in this case) of kidnaping and assault with intent to murder and was awaiting imprisonment on this offense with a life sentence. On the present charge, defendant was sentenced to serve a consecutive sentence of 7-10 years. Upon review, the term was left unchanged but made concurrent with his life sentence.

Mitigating:

-consecutive sentence to life seemed extravagant 
Table 17 summarizes the inferred reasons in each case. The harvest, as can be seen, is unsatisfactory.

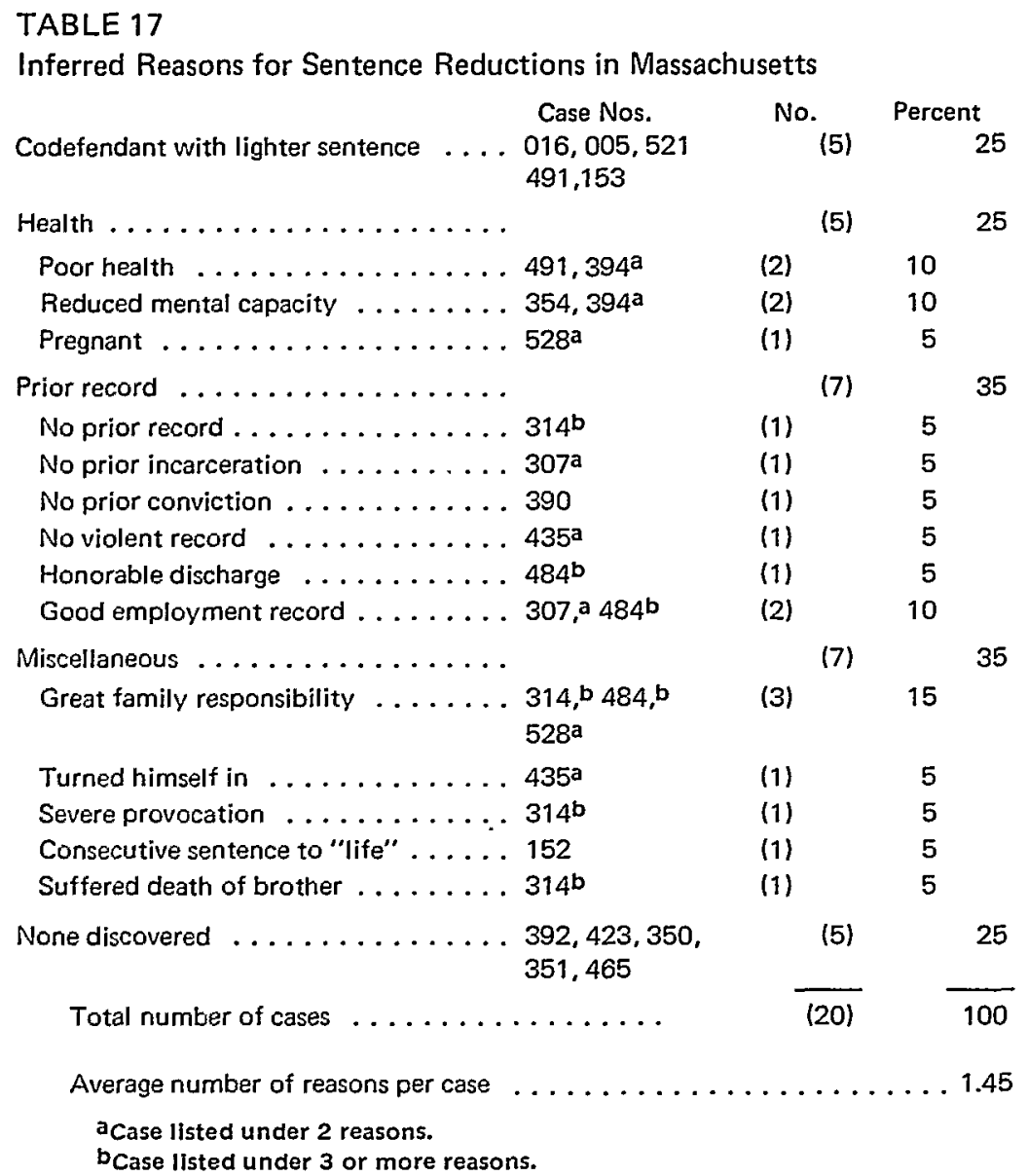

Except for the 5 cases of the 20 in which the different sentence of a codefendant was the reason for the reduction, the reasons we were able to infer from these Massachusetts cases are unsatisfactory. That is to say, the remaining 15 cases ( 75 percent of all) are the counterpart of category (5) (sentence too severe) of the corresponding Connecticut review division, as detailed in table 15 , which provides at best an incomplete explanation and at worst none at all.

\section{SENTENCE INCREASES}

In both Massachusetts and Connecticut every sentenced offender is 
warned, before his case is reviewed, that the division has the right to increase his sentence. The provision serves to discourage applications for review, and our data suggest that this warning serves this purpose. Appeal rates in Connecticut (which has not increased a sentence since 1963) are higher than in Massachusetts.

Nor is sentence increase a frequent occurrence in Massachusetts. Only about one in eleven sentence modifications (or about 2 out of every 1,000 sentences eligible for review) involves a sentence increase.

Since our Massachusetts sample happens to contain no increases, we had to dip into the past. In Connecticut this was not difficult because some of these cases had been published. In Massachusetts the office of the Executive Secretary helped us to find seven cases spanning a time period of fifteen years. ${ }^{61}$

The eight sentence increases in Connecticut involve either particularly vicious crimes or offenders who had committed a great number of crimes. Typical of the latter category is the Davis case. ${ }^{62}$ The defendant, who was convicted of attempting to obtain money under false pretenses, as a second offender received a 1-3 year prison term. Between 1937 and 1958, Davis had been convicted of 18 crimes. One of his previous convictions had been for the same type of crime and he had obtained a sentence of 11/2-3 years. The division increased the 1-3 year term to 2-5 years, stating that the penalty for a second offense must be more severe than the last penalty received for the same type of crime.

The violent crimes committed by the defendants whose sentences were increased included rape and assault with intent to murder. ${ }^{63}$ All involved the use, or threatened use, of weapons. Several of the incidents involved serious injury to the victim. Four of the five defendants had at least one prior felony conviction. The division described the attacks in several opinions as vicious.

All the seven Massachusetts instances of sentence increase involve very serious crimes and severe original sentences. The sentence minimum ranges from 5 years (in three cases) to 15 years (in two cases).

In case 1 of table 18 , a dealer in drugs had promised, prior to sentencing, to cooperate with the prosecutor and the police in identifying the higher-ups in the chain, but subsequently reneged. The

61. We are indebted to John Fiske, the executive secretary of the Massachusetts Superior Court and to John O'Connor of the Suffolk County Probation Department for their help, and to Kathy O'Connell who located these seven cases in the Suffolk County file.

62. State v. Davis, 21 Conn. Supp. 480,158 A.2d 601 (1959).

63. Unpublished opinion (1958); State v. Langley, 22 Conn. Supp. 492,174 A.2d 689 (1961); State v. Levac, 25 Conn. Supp. 68, 196 A.2d 603 (1963); State v. Rodgers, 23 Conn. Supp. 83, 176 A.2d 600 (1961); State v. Kohlfuss, 22 Conn. Supp. 278, 169 A.2d 659 (1961). 
defendant in case 2 was convicted of armed robbery with a machine gun. He too had promised cooperation but when his codefendant came to trial, he exonerated him. In case 5, the conviction was for assault with intent to rob. When the defendant appealed, his sentence was increased from 7-10 years to 8-10 years. We learn that two codefendants received 7-10-year sentences, but that the defendant was the one who had committed the assault-breaking a bottle over the victim's head. In the armed robbery case, case 7, the 5-7-year sentence was increased to 7-10 years. The codefendant had received 10-12 years, so this seemed a partial adjustment of the discrepancy.

TABLE 18

Sentence Increases in Massachusetts

\begin{tabular}{cccccl} 
Case No. & Year & $\begin{array}{c}\text { cence } \\
\text { Original } \\
\text { Sinimum } \\
\text { (Years) }\end{array}$ & $\begin{array}{c}\text { Minimum } \\
\text { Sentence } \\
\text { After } \\
\text { Review } \\
\text { (Years) }\end{array}$ & $\begin{array}{c}\text { Percent } \\
\text { Increase }\end{array}$ & \multicolumn{1}{c}{ Crime } \\
$\ldots \ldots \ldots$ & 1976 & 8 & 12 & 33 & Armed kidnaping \\
$2 \ldots \ldots \ldots$ & 1972 & 15 & 20 & 25 & Armed robbery \\
$3 \ldots \ldots \ldots$ & 1967 & 5 & 7 & 40 & Drug dealing \\
$4 \ldots \ldots \ldots$ & 1967 & 7 & 8 & 16 & Attempted robbery \\
$5 \ldots \ldots \ldots$ & 1962 & 15 & 18 & 20 & Rape \\
$6 \ldots \ldots$ & 1961 & 5 & 8 & 60 & Sodomy \\
$7 \ldots \ldots \ldots$ & 1961 & 5 & 7 & 40 & Armed robbery
\end{tabular}

Average increase $\ldots \ldots \ldots \ldots \ldots \ldots \ldots .33$

In the remaining three cases we have no hint as to what made the judges take the unusual step. In case 4 the defendant was convicted of forcible sodomy with a teenager. The board increased his minimum sentence from 5 to 8 years. Case 3 is, on the record, particularly puzzling. The defendant was one of three convicted for kidnaping and armed robbery. All received sentences of 8-15 years. On review, this defendant, although he had no prior record, had his sentence increased to $12-15$ years. In case 6, a 23-year-old boy raped and severely injured a 22-year-old girl. The defendant had a long record and was on parole when he committed the current offense. His sentence of 15-20 years was changed to $18-20$ years.

Reasons for increases fall into three discernible categories: increases because the sentence was out of line with that of a codefendant; increases because the offender failed to keep his promise to cooperate with the prosecution, made prior to the imposition of the 
original sentence; increases because the board considered the original sentence too low.

Understandably, several offenders whose sentences were increased in response to their appeal for a reduction subsequently tried to attack the decision. Four such offenders in Connecticut challenged the constitutionality of the increases, and all four were successful in their efforts to have the increased sentence set aside-albeit on extraneous grounds and not because sentence increase after appeal by the defendant was in itself considered unlawful. Defendant Kohlfuss was not successful in his first challenge to the sentence increase, in which he argued that an increase in penalty and resentencing put him twice in jeopardy for the same crime. ${ }^{6}$ The Connecticut Supreme Court of Errors rejected this claim as unmeritorious, relying on Kohlfuss's knowledge that his review could result in a sentence increase and his decision to apply nevertheless for review. Later, Kohlfuss petitioned for a writ of habeas corpus, alleging that he had been denied his Sixth and Fourteenth Amendment rights to representation by counsel. The federal court that decided the case in his favor noted in its opinion that none of the defendants whose sentences had been increased had been represented by counsel. ${ }^{65}$ After the Kohlfuss case, two other prisoners whose sentences had been increased made the same claim to Connecticut courts and had their sentence increases set aside.

Another successful attack on the sentence increase was mounted by a man named Heyward, whose sentence had been ordered increased from 5-7 to 5-10 years by SRD. ${ }^{66}$ Because Heyward was not actually resentenced to the 5-10-year term until the 5-7-year term expired, the Connecticut Supreme Court granted Heyward's petition for a writ of habeas corpus and ordered his immediate release on the grounds that his constitutional (due process and double jeopardy) rights had been violated by the procedure in this case. ${ }^{67}$

The success of these legal attacks on sentence increases might be one of the reasons that persuaded the Connecticut review division to cease increasing sentences.

In Massachusetts, too, offenders who, on application for review, had their sentences increased tried to obtain redress in court. They were, however, not successful.

In the most recent of these cases, Gavin v. Commonwealth (with 
two companion cases), ${ }^{68}$ the offenders claimed that their constitutional rights had been violated by the division's failure to give a statement of reasons for its order to increase the sentences. In 1975 the case reached the Supreme Judicial Court of Massachusetts, which rejected the claim on the grounds that neither the statute which created the Appellate Division nor the Constitution required a statement of reasons.

Petitioners had claimed, among other arguments, that Nortb Carolina $v$. Pearce ${ }^{69}$ was applicable, in which the U.S. Supreme Court held that:

[W] henever a judge imposes a more severe sentence upon a defendant after a new trial, the reasons for his doing so must affirmatively appear. Those reasons must be based upon objective information concerning identifiable conduct on the part of the defendant occurring after the time of the original sentencing proceeding.

The rationale for the holding was the possibility that "pique at the 'wasted' time and effort and the like, even though subconscious, may in some degree have motivated the sentence."70 The Massachusetts court noted that in the instant case there was not even a hint of such a motive and dismissed the argument.

Decisions to increase the sentence on review, however, are open to another kind of suspicion. The statute empowering the division to increase the sentence at its discretion was enacted for a purpose: namely, to discourage applications for review of every eligible sentence. It could therefore be argued that the division is determined to have at least one or two increases each year in order to reaffirm the reality of the threat; moreover, if deterrence of applications without merit is a motive, the division might increase the proportion of lengthened sentences in years where more cases are brought before it. The available figures give no support to either of these suspicions.

Table 19 shows that the highest percentage of sentence increases occurred in 1970, when the number of cases heard was at a minimum (66); that during one year (1969) there was not a single increase; and that during 1973, the year with the second highest caseload (267), there was but one increase.

68. Gavin v. Commonwealth, 327 N.E.2d 707 (1975), aff'd sub nom. Gavin v. Chernoff, 546 F.2d 457 (1st Cir. 1976). Information on these cases was obtained from Justice Kaplan, who wrote the opinion for the Supreme Judicial Court of Massachusetts denying the offenders' right to redress of their sentence increases.

69. 395 U.S. 711 (1969).

70. Gavin v. Commonwealth, 327 N.E.2d 707, 710 (1975), aff'd sub nom. Gavin v. Chernoff, 546 F.2d 457 (1st Cir. 1976). 
TABLE 19

Patterns of Dispositions in Massachusetts, 1969-73a (Percent)

\begin{tabular}{|c|c|c|c|c|c|}
\hline Sentence & $\begin{array}{c}1969 \\
(N=107)\end{array}$ & $\begin{array}{c}1970 \\
(N=66)\end{array}$ & $\begin{array}{c}1971 \\
(N=109)\end{array}$ & $\begin{array}{c}1972 \\
(N=386)\end{array}$ & $\begin{array}{c}1973 \\
(N=267)\end{array}$ \\
\hline Affirmed ... & 84 & 78 & 74 & 83 & 87 \\
\hline Reduced ... & 16 & 17 & 23 & 15 & 13 \\
\hline Increased ... & $\cdots$ & 5 & 3 & 2 & * \\
\hline Total ... & 100 & 100 & 100 & 100 & 100 \\
\hline
\end{tabular}

There is, nevertheless, a lingering feeling that not all is right with the decisions to increase a sentence, even if there is a good reason for it in the individual case. The division, after all, sees only the upper part of the sentence spectrum. The judges, therefore, do not see all or even nearly all offenders whose original sentences were "too low." It is safe to assume that the bulk of the too-low sentences must be among the sentences that never come before the division. Whenever the division increases a sentence, it increases one of the severe sentences, which it did not consider severe enough. The average minimum sentence of the seven Massachusetts sentence increases studied was $8 \frac{1}{2}$ years.

\section{THE VALUE OF STATED "REASONS"}

The case for having the review division state its reasons was engagingly made by Justice Kaplan, writing for the Massachusetts Supreme Judicial Court in the Gavin case, which ultimately held that the absence of a statement of reasons did not void an imposed sentence increase:

On the affirmative side, it may be suggested that the preparation of such a statement would provide a test for the judges themselves, and for the prisoner also, of the soundness of the judges' reasoning.... The statement would be some guaranty that the decision was not capricious or arbitrary, a safeguard perhaps especially needed if the decision to resentence is indeed "final." We can recognize that there is more than mere sentimental attractiveness in the idea that an explanation is "owed" to the prisoner on whom a harsher sentence has been imposed after he has pleaded for a reduction; if the explanation would not help materially in his rehabilitation, it would at least symbolize that he was being treated as a person rather than a cipher. A statement of reasons might usually be more easily written by the Appellate Division for revising a sentence than by the trial judge for imposing the original sentence, since the former would be a more focused analysis looking to correction of 
possible misjudgment embodied in the sentence reviewed rather than to the formation of an original judgment. ${ }^{71}$

Much depends on whether reason statements can be formulated that fulfill this explanatory function. Justice Kaplan had his doubts, and we shall return to them later on.

The precise question to address here is what logical structure reasons must have in order to provide a satisfactory explanation. Let us begin with some of the satisfactory explanations we have found in the present study. When the division increases a sentence and, for instance, states:

This sentence will be increased because it is smaller than the last sentence this offender received for a similar crime,

we have been given a full explanation. If the division states:

This sentence will not be changed since it was agreed to by the defendant when he pleaded guilty,

we have been given a full explanation. If the division states:

This sentence is being reduced so as to equal the lower sentence a codefendant has received whose criminal responsibility in this was not less than the petitioner's and whose record was comparable,

we have been given a full explanation. If the Massachusetts division (which does not make statements of reasons) would have stated (in case 1): ${ }^{72}$

The sentence of this appellant will be increased because at the time of sentencing he promised cooperation with the prosecutor, a promise he did not keep,

we would have had a full explanation.

All four explanations-as would all full explanations-have this in common: they express or imply a rule of which the instant case is a special application.

If circumstance $\mathrm{X}$, or the combination of circumstances $\mathrm{X}, \mathrm{Y}$, and $\mathrm{Z}$ are present, the review division will act in the indicated manner.

The rule, much like the holding in a court opinion, may have been established earlier and only reapplied in the instant case. The rule would provide an "explanation" even if it should be considered unfair. Sup-

71. See id. at 712-13.

72. See text at table 18. 
pose the Massachusetts division were to state (as it might truthfully in some cases):

The sentence will stand because we do not reduce, as a rule, any sentence that does not exceed 5 years,

we would have a full explanation.

All these rules into which the full explanations could be translated have another characteristic in common. They contain fairly precise prescriptions as to the type of sentencing decision to make and whether to affirm, reduce, or increase the sentence.

In contrast, we now turn to examples of reasons that fail to provide a full explanation, and at times any explanation. There follow some reason statements in cases in which the division affirmed the sentence:

- We cannot say that the sentence imposed is out of line.

- We cannot say that the sentence is too harsh.

- There is nothing wrong with the sentences that are within the statutory limits. Nor can the division say that the sentencing judge exceeded his discretionary authority.

- There are no facts appearing to give countenance to any abuse of discretion by the sentencing judge in imposing the sentence, which did not exceed the statutory limits for the offense charged.

Following is the complete text of an unusually detailed statement of facts and reasons:

On June 6,1974 , as a result of a plea of guilty, the petitioner received a sentence of not less than eight nor more than twenty years for the crime of manslaughter in the first degree in violation of Public Act No. 73-137, Section 9(a)(3) of the 1973 Public Acts of the General Assembly.

On March 5, 1974, the petitioner had an argument with his girl friend, striking her in the face. On March 6,1974, the victim, who was also seeing the same girl, noticed that her face was swollen and told her to talk to the petitioner about leaving her alone. The following day, the victim went to where the petitioner was employed, to speak to him about the girl. They got into an argument, which continued for some time, and glasses and chairs were broken. The petitioner took a gun from behind the bar but put it back. Both parties to the argument went outside. They then continued their argument inside. The petitioner again took the gun from behind the bar and shot the victim. The victim expired as a result of two gunshot wounds.

The petitioner has no criminal record, except for a conviction for disorderly conduct. He is remorseful. His attorney urged the court to impose a five year minimum.

The victim had no weapon and had not been drinking. The blood alcohol 
was negative. The State's Attorney recommended the sentence imposed by the court. The sentencing judge felt that the recommendation was a fair one.

The fact that a human life has been taken is an important element in sentencing. The division cannot say that the sentence was unreasonable or severe. It is within statutory limits. It must stand.

Accordingly, the sentence is affirmed. ${ }^{73}$

None of these statements provides any explanation. This can best be seen if we take the liberty of slightly rearranging this opinion:

... as a result of a plea of guilty, the petitioner received a sentence of not less than eight ... years....

The victim had no weapon and had not been drinking. The blood alcohol was negative. It is true that the State's Attorney recommended the sentence imposed by the court and that the sentencing judge felt that the recommendation was a fair one. The fact that a human life has been taken is an important element in the sentencing.

On the other hand, the petitioner has no criminal record, except for a conviction for disorderly conduct. He is remorseful. His attorney urged the court to impose a five-year minimum.

In view of these important mitigating circumstances, the division felt that justice would be better served if petitioner's minimum sentence were reduced to five years.

It is so ordered.

We have left the statements of mitigating and aggravating circumstances untouched, merely reversed their order, but we have changed the conclusion. One decision would have been as plausible as the other. Since no rule is invoked either way, the enumeration of mitigating and aggravating circumstances is of little relevance. As long as there are some of each, they can support either decision. Neither would be based on a discernible rule.

The criterion, of course, goes only to the statement of the reasons, not to the reasons themselves. The division, unless it acts capriciously, which would be an unfair assumption, operates in all these cases under the rule it expressed in case 182 :

This sentence is too severe when compared to others convicted of the same offense with similar histories.

This is a satisfactory explanation except that the proof is missing. In a rudimentary way we have attempted to supply that proof in table 20 .

In table 20 we have put side by side the original sentence in the case, the ordered reduced sentence, and the average for cases of this

73. Unpublished decision (1974). 


\section{TABLE 20}

Reduction of Sentence Minimum as Compared to Average for "Comparable" Casesa (Massachusetts)

\begin{tabular}{|c|c|c|c|c|c|c|}
\hline \multirow{2}{*}{\multicolumn{2}{|c|}{ Case No. }} & $\begin{array}{c}\text { Reduction } \\
\text { (Years) }\end{array}$ & $\begin{array}{l}\text { tion } \\
\text { (s) }\end{array}$ & \multicolumn{2}{|c|}{ Average Sentence for "Comparable" Cases } & \multirow{2}{*}{$\begin{array}{l}\text { Reduction } \\
\text { with Regard } \\
\text { to Average }\end{array}$} \\
\hline & & From & To & (Years) & Case & \\
\hline 016 & $\ldots$ & 10 & 7 & 5 & $\begin{array}{l}\text { Guilty plea to armed robbery, } \\
\text { prior record (no incarceration) }\end{array}$ & toward \\
\hline 005 & $\cdots$ & 10 & 7 & 6 & $\begin{array}{l}\text { Guilty plea to armed robbery, } \\
\text { prior record of incarceration }\end{array}$ & toward \\
\hline 521 & $\ldots$ & 15 & 10 (max.) & 10 & $\begin{array}{l}\text { Max. sentence for guilty plea to } \\
\text { armed robbery, prior record of } \\
\text { incarceration }\end{array}$ & toward \\
\hline 302 & $\ldots$ & $71 / 2$ & 5 & 5 & $\begin{array}{l}\text { Assault and battery with deadly } \\
\text { weapon, prior record of incar- } \\
\text { ceration }\end{array}$ & toward \\
\hline 307 & $\ldots$ & 8 & 5 & 6 & $\begin{array}{l}\text { Possession with intent to sell- } \\
\text { class } A \text {, no prior record }\end{array}$ & beyond \\
\hline 314 & $\cdots$ & 9 & $21 / 2$ & 6 & $\begin{array}{l}\text { Assault with deadly weapon, after } \\
\text { jury trial, no prior record }\end{array}$ & beyond \\
\hline 354 & $\ldots$ & 25 & 10 & 10 & Rape, prior record & toward \\
\hline 390 & $\ldots$ & 12 & 9 & 9 & Rape, no prior record & toward \\
\hline 392 & $\ldots$ & 5 & $2 \frac{1}{2}$ & 3 & $\begin{array}{l}\text { Possession with intent to sell- } \\
\text { class B }\end{array}$ & beyond \\
\hline 394 & $\ldots$ & 4 & 2 & 8 & $\begin{array}{l}\text { Assault and battery with deadly } \\
\text { weapon, jury conviction, prior } \\
\text { prison record }\end{array}$ & away from \\
\hline 423 & $\ldots$ & 18 & 15 & 14 & $\begin{array}{l}\text { Sum of average for manslaughter } \\
\text { and average for robbery, major } \\
\text { record }\end{array}$ & toward \\
\hline 435 & $\cdots$ & 12 & 4 & 8 & $\begin{array}{l}\text { Manslaughter, without violent } \\
\text { record }\end{array}$ & beyond \\
\hline 350 & $\ldots$ & life & 8 & 5 & $\begin{array}{l}\text { Guilty plea to armed robbery, } \\
\text { prior record (no incarceration) }\end{array}$ & toward \\
\hline 351 & $\ldots$ & life & 8 & 5 & $\begin{array}{l}\text { Guilty plea to armed robbery, } \\
\text { prior record (no incarceration) }\end{array}$ & toward \\
\hline 465 & $\ldots$ & 10 & 9 & 6 & $\begin{array}{l}\text { Assault and battery with deadly } \\
\text { weapon, prior record }\end{array}$ & toward \\
\hline 484 & $\ldots$ & 5 & 4 & 5 & $\begin{array}{l}\text { Assault, guilty plea, felony } \\
\text { record }\end{array}$ & away from \\
\hline
\end{tabular}


sort. The juxtapositions are crude, because our inventory of cases was small. For the 16 (out of 20) cases for which we could compute at least some tentative averages, 10 modifications moved toward them; 4 moved toward the average but stopped beyond it so that the reduced sentence ended up below the average for the category. In only two cases did the reduction move away from the average.

But if table 20 is a true representation of the principle by which the division is guided in these decisions, then it is clear that a complete statement of reasons must contain some of these crucial numbers which would then form a more important part of the explanation than words can provide. Word-reasons are full explanations only when they refer to operating rules that translate mitigating and aggravating circumstances into points on a sentencing scale. Justice Kaplan saw the point clearly: 74

If our statutes provided fixed substantive rules as to the imposition of appellate review of sentences, then a statement of reasons could help to determine whether the rules were being followed or a given sentence was right. Whether or to what extent sentencing can or should be submitted to such substantive rules need not be debated here. The fact is that our sentencing conforms to the old and still conventional model without fixed rules (apart from those establishing durational or similar limits of sentences) that allows very. wide discretion to the trial judge. Thus an explanatory statement at the time of sentencing would serve no sharp analytic purpose [emphasis added].

An example of such a translation rule for sentences is the rule established by the United States Supreme Court in Gregg v. Georgia:

While the jury is permitted to consider any aggravating or mitigating circumstances, it must find and identify at least one statutory aggravating factor before it may impose the penalty of death. ${ }^{75}$

But such sentencing provisions are the exception, not the rule.

A developed appellate system of sentencing review with reasoned opinions can undoubtedly do better than the rudimentary beginnings in Connecticut. Yet even a developed system can have only a limited scope unless it establishes rules that translate circumstances into points on the sentencing scale. ${ }^{76}$

74. Gavin v. Commonwealth, 327 N.E.2d 707, 713 (1975), aff'd sub nom. Gavin v. Chernoff, 546 F.2d 457 (1st Cir. 1976).

75. Gregg v. Georgia, 428 U.S. 153, 206.

76. The Austrian Minister of Justice, Dr. Christian Broda, has commissioned a study of the Austrian sentence appellate system which gives broad appellate rights to both the defendant and the prosecutor. It will be instructive to see the results of that study. 
In this context the English experience is of interest. It would appear that the intelligence imparted through the case-by-case decisions of the Court of Appeals provided the raw material for guidelines but not the guidelines themselves, for they were developed in a scholarly book, Principles of Sentencing, by David Thomas. ${ }^{7}$ He has distilled from the collected decisions of the Court of Appeals what one might call "the tariff" for a great variety of specific crime-offender combinations. Trial judges, we are told, keep the book handy. ${ }^{78}$

\section{THE SEARCH FOR EQUITY}

The sentencing review board was created in an effort to curb sentence disparity in our criminal courts. Informal sentencing seminars and sentencing councils ${ }^{79}$ prior to imposing sentence are others. American law does not know as yet the independent appeal of the sentence to a higher court. All these efforts aim directly or indirectly at reducing sentence disparity at the trial level either by ad hoc modification or, more importantly-if less frequently, by developing sentencing guidelines.

The basic structure of the sentencing process is simple. The first decision is between incarcerating the offender or letting him "walk" by imposing a fine, probation, suspended sentence, or any other available variant that fulfills this purpose. The second decision concerns the length of incarceration, if incarceration is decided upon.

The basic need is for guidelines that translate specific crime-offender combinations into these decision issues. Occasionally the law does this by having special sentences for degrees of aggravation or for offenders with different prior records. What is needed are systematic guidelines that cover not only special situations but all possible combinations.

Such guidelines, if they are to reduce disparity, must be specific enough to identify comparable cases and flexible enough not to do violence to the sentencing judge's need for differentiation.

Merely requiring reasons from the sentencing judge or from the review board is unlikely to help much, as the Connecticut experience

77. David A. Thomas, Principles of Sentencing: The Sentencing Policy of the Court of Appeal Criminal Division (London: Heinemann Educational Books, Ltd., 1970).

78. Here ends our review of the sentencing review procedures in Massachusetts and Connecticut. Our findings are not complete. We have as yet no measure of the sentence disparity in these courts. We would like to know how disparity changes over time, especially whether service on the review board tends to reduce disparity when these judges impose sentence in the trial courts. We would also like to know more about the board's own view of its role and how it goes about making its decisions.

79. See note 4 supra. 
shows. Genuine guidelines must relate specific offender-crime combinations to the sentencing decisions.

The important pioneering work toward this goal has been done by Leslie Wilkins and his associates. ${ }^{80}$ The principle underlying that work is simple: find out what the judges in fact do; see whether their actions show any discernible pattern; then establish that pattern as a guideline. Table 21, freely adapted from Wilkins's work for the present purpose, shows how such guidelines might look. The point scores for offender and crime reflect the circumstances the judges actually take into consideration. The offender score is primarily determined by the past criminal record, if any; the crime score reflects both the seriousness of the type of offense and the aggravating and mitigating circumstances of the particular case.

\section{TABLE 21}

Suggested Maximum Sentence

\begin{tabular}{|c|c|c|c|c|c|c|}
\cline { 2 - 7 } \multicolumn{2}{c|}{} & \multicolumn{6}{c|}{ Offender Score } \\
\cline { 2 - 7 } \multicolumn{2}{c|}{} & $1-5$ & $6-10$ & $11-15$ & $16-20$ & $21-25$ \\
\hline \multirow{4}{*}{$心$} & $1-5$ & Walk & Walk & Walk & Walk & 4 yrs. \\
\cline { 2 - 7 } & $6-10$ & Walk & Walk & Walk & 4 yrs. & 6 yrs. \\
\cline { 2 - 7 } & $11-15$ & Walk & Walk & 4 yrs. & 6 yrs. & 8 yrs. \\
\cline { 2 - 7 } & $16-20$ & Walk & 4 yrs. & 6 yrs. & 8 yrs. & 10 yrs. \\
\cline { 2 - 7 } & $21-25$ & 4 yrs. & 6 yrs. & 8 yrs. & 10 yrs. & 15 yrs. \\
\hline
\end{tabular}

Guidelines, of course, are no more than that; they are not mandatory rules. One of the bills now pending in the Congress ${ }^{8} 1$ intends to foster acceptance by imposing a twofold burden on the judge who deviates from the guidelines: the judge must give reasons for the deviation, and the sentence may be appealed.

The construction of guidelines involves a number of problems: the Wilkins guidelines have no lower sentence limit and therefore bypass the problem of a possible sentence appeal by the prosecutor. Traditionally, American and English law does not allow the prosecutor to appeal a

80. Leslie T. Wilkins et al., Sentencing Guidelines: Structuring Judicial Discretion (mimeographed 1976); Leslie T. Wilkins, Perspectives on Court Decision-making, in Don M. Gottfredson, ed., for National Institute of Mental Health, Center for Studies of Crime and Delinquency, Decision-making in the Criminal Justice System: Reviews and Essays 59 (Washington: Government Printing Office, 1975).

81. S. 1437, 94th Cong., 2d Sess. (1976). 
sentence as too low. In Canada, the Crown with leave from the court may appeal a sentence. England, however, allows the court to increase a sentence imposed by the Magistrate Court that was appealed by the defendant.

Another problem arises from the need for periodic revision of the guidelines. Recent years, for instance, have brought sharp upward shifts in sentencing patterns, most of them within the unbounded discretion of the present laws. The necessary periodic revisions might not only affect the numbers in the body of the guideline table but also the point values that compose the scores of offender and crime.

Withal, acceptance of elaborate sentencing rules, however desirable a goal, might not be achieved easily. The basic problem is to make the judges see the problem of lateral disparity and encourage them to reduce it. And since such an adjustment may conflict with the judge's personal sense of justice, a more modest beginning might be a useful first step. We would propose that all judges about to impose sentence be made aware of the sentence pattern that their court or the system as a whole imposes in cases involving that particular crime-offender combination. The particular combinations should perhaps appear in their original descriptive form, not as yet in point scores; in the mathematical transformation, important concreteness is lost.

One might begin the crime classification with the broad categories that some of the penal codes have established, such as the Federal Penal Code or the Penal Law of New York State. The latter, for instance, distinguishes among felonies $\mathrm{A}, \mathrm{B}, \mathrm{C}, \mathrm{D}$, and $\mathrm{E}$, misdemeanors $\mathrm{A}$ and $\mathrm{B}$, violations, and infractions. As a next step one could perhaps refine these broad classifications by distinguishing particularly the now very important violent crimes.

One might begin the offender classification by accepting the traditional crime record distinction of no prior record, arrests only, ${ }^{82}$ convictions without incarcerations, and prior incarcerations. Successive refinements, which depend in part on a sufficiently large number of available cases, would enable a judge to see, for instance, what sentences his court imposed on a convicted store burglar who had a record of prior incarcerations for similar crimes.

There is no need to make any of these classifications or combina-

82. We are bypassing the important issue as to whether a record of arrests only should be at all distinguished from no record. 
tions permanent. Even without the use of a computer, they can be changed easily; with a computer, they can be changed instantaneously. 83

The operation would begin by assembling all sentences for a given category as shown in figure 1 .

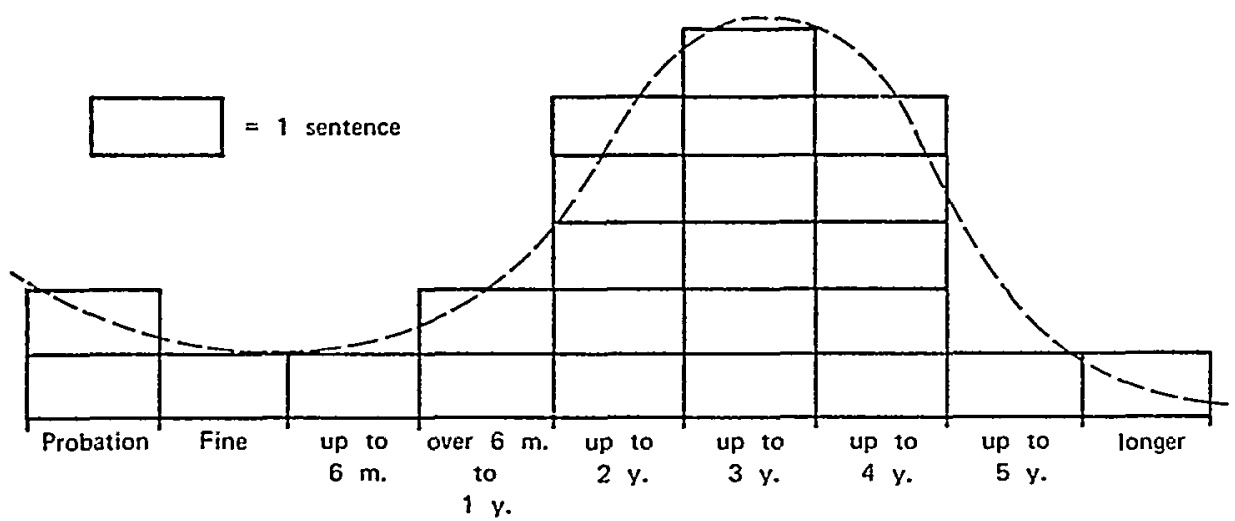

Fig. 1. Assembling the Sentences Imposed by the Court for Specific Crime-Offender Combinations.

Just what these distributions will look like is impossible to predict. They might approximate any of the four prototypes shown in figure 2 .

They may be symmetrically distributed, as in (a) of figure 2; skewed at the lower or upper limit of the sentencing frame, as in (b); or even bimodal, as in (c), when judges are so far apart from each other that some gave the minimum and some the maximum sentence. It is, of course, quite possible that for some offender-crime combinations there is no such thing as a prevalent pattern for a court, only a diversity so great that the distribution curve has no peak and remains flat, as in (d). This type of sentencing pattern provides no guidance to the judge who would like to conform. But such a curve should be a signal that sentencing is so much in need of help that remedial planning is in order.

83. From the record of such entries we could learn more precisely what case characteristics judges use in their sentencing decicions. 
(a)

Symmetrical

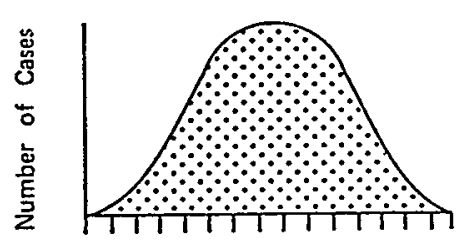

(c)

Bimodal (b)

Skewed

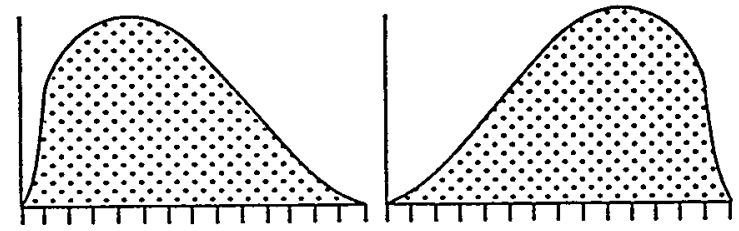

Severity of Sentence

(d)

Complete Dispersion
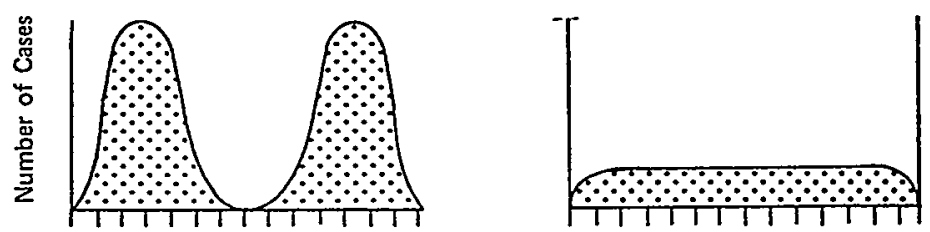

Fig. 2. The Type of Possible Distributions

Once the distributions are established, they should be converted to a percent basis so as to make them comparable, irrespective of the different number of cases they might contain. Next, one might consider spelling out the average (mean) sentence and certain specified ranges, as shown in figure 3 .

The availability of such sentence distributions for all crime-offender combinations would facilitate the task of the review board; the distributions would replace with hard figures the heretofore intuitive and hence vague Gestalt perceptions that normally inform the review process.

These distributions should also be welcome information for the trial judges because they would put the lateral disparity problem permanently before them. While some judges might not care, most of them 


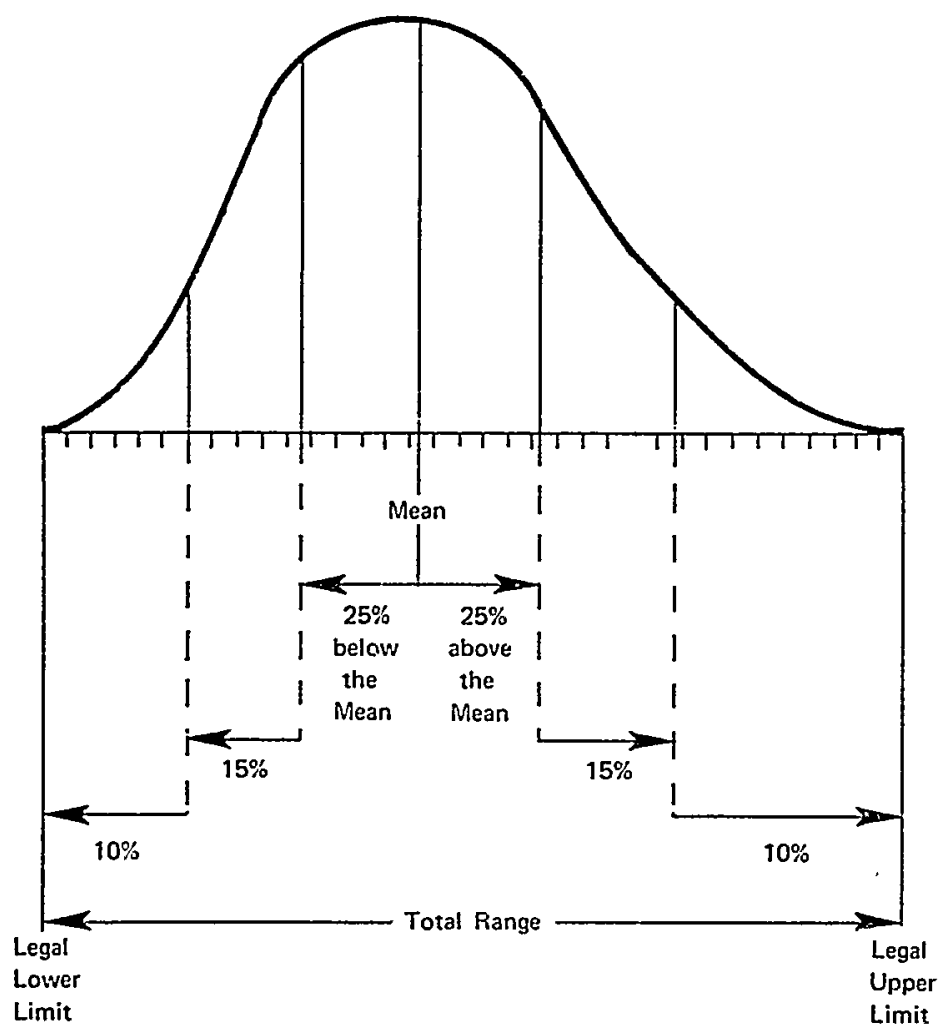

Fig. 3. Grouping the Distribution of Sentences Imposed By the Court for a Specific CrimeOffender Combination.

would appreciate permanent visibility of the problem and the implied gentle nudgings toward reducing disparity. ${ }^{84}$ Whatever these distribu-

84. From time to time the judges might care to see even more specifically how their own sentencing pattern compares with those of their colleagues.

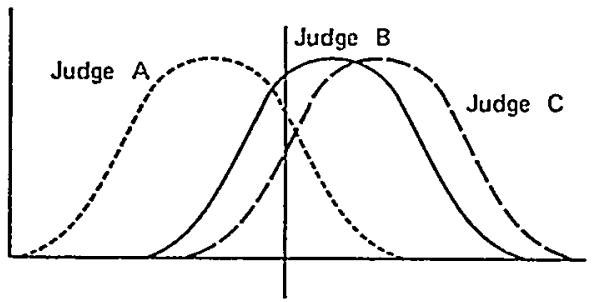

Average

All Judges

Fig. 4. Sentence Distributions of Individual Judges for Specific Crime-Offender Combinations. 
tions show-whether a prevalent pattern or rampant disparity-they will provide important information. Having this information will not resolve the disparity problem, but it will help to narrow its dimensions. Looking at the actual sentencing pattern will be a useful first step toward the development and eventual acceptance of specific guidelines, either by building up the prevalent pattern, or by reforming it, or in some cases possibly by beginning to establish it. 